\title{
Efficacy of varying rates of herbicide and surfactant for the control of understory oriental bittersweet (Celastrus orbiculatus Thunb.) plants in an Appalachian hardwood forest
}

Terry L. Burhans Jr.

West Virginia University

Follow this and additional works at: https://researchrepository.wvu.edu/etd

\section{Recommended Citation}

Burhans, Terry L. Jr., "Efficacy of varying rates of herbicide and surfactant for the control of understory oriental bittersweet (Celastrus orbiculatus Thunb.) plants in an Appalachian hardwood forest" (2012). Graduate Theses, Dissertations, and Problem Reports. 3530.

https://researchrepository.wvu.edu/etd/3530

This Thesis is protected by copyright and/or related rights. It has been brought to you by the The Research Repository @ WVU with permission from the rights-holder(s). You are free to use this Thesis in any way that is permitted by the copyright and related rights legislation that applies to your use. For other uses you must obtain permission from the rights-holder(s) directly, unless additional rights are indicated by a Creative Commons license in the record and/ or on the work itself. This Thesis has been accepted for inclusion in WVU Graduate Theses, Dissertations, and Problem Reports collection by an authorized administrator of The Research Repository @ WVU. For more information, please contact researchrepository@mail.wvu.edu. 
Efficacy of varying rates of herbicide and surfactant for the control of understory oriental bittersweet (Celastrus orbiculatus Thunb.) plants in an Appalachian hardwood forest

\title{
Terry L Burhans Jr
}

\author{
Thesis submitted to the \\ Davis College of Agriculture, Natural Resources and Design \\ at West Virginia University \\ in partial fulfillment of the requirements \\ for the degree of
Master of Science
in
Forestry

David W. McGill, Ph.D., Chair

John R. Brooks, Ph.D.

Rakesh Chandran, Ph.D.

Division of Forestry

Morgantown, WV

2012

Keywords: Celastrus, understory, oriental bittersweet, glyphosate, herbicide, exotic-invasive, surfactant 


\begin{abstract}
Efficacy of varying rates of herbicide and surfactant for the control of understory oriental bittersweet (Celastrus orbiculatus Thunb.) plants in an Appalachian hardwood forest

Terry L Burhans Jr

Oriental bittersweet (Celastrus orbiculatus) is an invasive climbing, twining vine that can grow up into the forest canopy effectively inhibiting growth and light exposure on affected trees. A local landowner who had treated bittersweet with various rates of a glyphosate-based herbicide claimed that higher than recommended rates of herbicide were needed to effectively control the invasive plant. This study was established to assess the validity of this claim and to explore the interaction of glyphosate and surfactant effects on the efficacy of bittersweet control. The goal was to determine an ideal treatment of herbicide and surfactant rates for the effective chemical control of $C$. orbiculatus. Four rates of glyphosate herbicide in the form of Accord Concentrate ${ }^{\circledR}(0 \%, 2.5 \%, 5 \%$, and $10 \%$ volume to volume) were crossed with four rates of a common surfactant (Cide-Kick II ${ }^{\circledR} ; 0 \%, 0.5 \%, 1 \%$, and $2 \%$ ) to create 16 treatments. Treatments were randomly assigned to individual plants growing in the understory of two forested areas in northern West Virginia. Five replicates for each treatment at each site were separated into discrete blocks to account for any microsite variation that might be present within the treatment area. Apart from the surfactant only treatments, all glyphosate treatments were highly effective in defoliating the bittersweet stems. This paper details the first-year results of the study and provides a glimpse of attributes that occur on this invasive species as a result of herbicide toxicity.
\end{abstract}




\section{Acknowledgements}

This project would not have come to fruition without the support of various individuals. First and foremost, I would like to thank my advisor, Dr. David W. McGill, for not only giving me a chance to expand and continue my education in the natural sciences with the Forestry department, but for also guiding me and providing support through this project, as well as other projects throughout my graduate career at West Virginia University. I would also sincerely like to thank the other members of my graduate committee, Dr. John Brooks and Dr. Rakesh Chandran, whose input, suggestions, and guidance have helped immensely in the design of this study and, more importantly the overall progression in my graduate studies. I would also like to thank John Burkhart for his statistical guidance and support.

I am very grateful to Mrs. and Mr. Brent Williams for their cooperation on this research project. They have been more than generous and accommodating in allowing me to carry out my study on their property. I am also grateful for the help and support of their forester, Mr. Juergen Wildman without whose cooperation, this study would not have been possible.

I would also like to thank Megan McCuen, Ellen Voss and Nic Persinger for their help during field preparations and applications. I would also like to thank my supervisor at the USDA Forest Service, Richard M. Turcotte for his continued support and advice throughout course of my project.

I am also grateful for the rest of my fellow Davis College graduate students for their moral support. Last but not Least, I would like to thank my parents, Terry and Denise Burhans for their life-long love, commitment, and continued encouragement. 
Table of Contents

\begin{tabular}{|c|c|c|}
\hline \multicolumn{2}{|l|}{ Photrost } & Page \\
\hline \multicolumn{2}{|l|}{ Abstract } & $\mathrm{i}$ \\
\hline \multicolumn{2}{|c|}{ Acknowledgements } & ii \\
\hline \multicolumn{2}{|c|}{ Table of Contents } & iii \\
\hline \multicolumn{2}{|c|}{ List of Figures } & iv \\
\hline \multicolumn{2}{|c|}{ List of Tables } & $\mathrm{v}$ \\
\hline \multicolumn{2}{|l|}{ Preface } & vi \\
\hline \multicolumn{3}{|c|}{ Chapter 1: Literature Review: Celastrus orbiculatus, a concern in the Appalachian Region } \\
\hline \multicolumn{2}{|c|}{ A. Introduction } & 1 \\
\hline \multicolumn{2}{|c|}{ B. Taxonomy and Description } & 3 \\
\hline \multicolumn{2}{|c|}{ C. Silvics } & 4 \\
\hline \multicolumn{2}{|c|}{ D. Problems } & 5 \\
\hline \multicolumn{2}{|c|}{ E. Site } & 6 \\
\hline \multicolumn{2}{|c|}{ F. Pathogens and Natural Enemies } & 7 \\
\hline \multicolumn{2}{|c|}{ G. Reproduction and Propagation } & 7 \\
\hline \multicolumn{2}{|c|}{ H. Invasive Properties } & 8 \\
\hline \multicolumn{2}{|c|}{ I. Possible Uses } & 9 \\
\hline \multicolumn{2}{|c|}{ J. Control } & 10 \\
\hline \multicolumn{2}{|c|}{ K. Literature Cited } & 13 \\
\hline \multicolumn{3}{|c|}{$\begin{array}{l}\text { Chapter 2: Effects of high rates of varying herbicide and surfactant levels on understory } \\
\text { Celastrus orbiculatus plants }\end{array}$} \\
\hline \multicolumn{2}{|c|}{ A. Introduction } & 19 \\
\hline \multicolumn{2}{|c|}{ B. Methods } & 20 \\
\hline i. & Study Sites and Stand Structure & 20 \\
\hline ii. & Understory Conditions & 29 \\
\hline iii. & Materials & 29 \\
\hline iv. & Average $C$. orbiculatus dimensions for selected stems & 31 \\
\hline v. & Experimental Design & 31 \\
\hline vi. & Application & 32 \\
\hline vii. & Analysis & 33 \\
\hline \multicolumn{2}{|c|}{ C. Results } & 39 \\
\hline i. & Survival & 39 \\
\hline ii. & Analysis of Week After Treatment of Attribute Appearance & 39 \\
\hline iii. & Timeline of attributes associated with $C$. orbiculatus herbicide damage & 42 \\
\hline \multicolumn{2}{|c|}{ D. Discussion } & 45 \\
\hline \multicolumn{2}{|c|}{ E. Conclusions } & 47 \\
\hline \multicolumn{2}{|c|}{ F. Literature Cited } & 49 \\
\hline
\end{tabular}




\section{List of Figures}

Figure

Page

Chapter 1: Literature Review: Celastrus orbiculatus, a concern in the Appalachian Region

1.01 States where $C$. orbiculatus is considered invasive. 2

1.02 C. orbiculatus stem growth pattern inhibiting growth of affected tree. 5

1.03 Constriction from Celastrus vine leads to abnormal growth in bole of Sassafras. 5

1.04 C. orbiculatus covering edge trees near Ashville, NC.

5

Chapter 2: Effects of high levels of varying herbicide and surfactant levels on understory $C$. orbiculatus plants

2.01 General location of study sites in North-Central West Virginia. 22

2.02 Study site at the West Virginia University Research Forest, Preston County, WV. 25

2.03 Study site in Colfax, Marion County, WV. 26

2.04 WVU Research Forest trees per acre by DBH $(\mathrm{cm})$ size class and species. $\quad 27$

$\begin{array}{ll}2.05 & \text { Colfax trees per acre by DBH }(\mathrm{cm}) \text { size class and species. }\end{array}$

2.06 WVU Research Forest basal area $\left(\mathrm{m}^{2}\right)$ per acre by DBH size class and species. 28

2.07 Colfax basal area $\left(\mathrm{m}^{2}\right)$ per acre by DBH size class and species. 28

2.08 Calibration Compression Sprayer fitted with a flat-spray tip. 30

2.09 Percent survival of plants by treatment, March, 2012.

2.10 Average appearance of attributes (WAT) for control plants. 44

2.11 Average appearance of attributes (WAT) for plants treated with surfactant only. 44

2.12 Average appearance of attributes (WAT) for Glyphosate-treated plants. 44

2.13 Appearance of attributes (WAT) for plants treated with recommended rates. $\quad 44$ 


\section{List of Tables}

Table

Page

Chapter 1: Literature Review: Celastrus orbiculatus a concern in the Appalachian Region

1.01 Useful traits for distinguishing $C$. scandens from $C$ orbiculatus.

4

1.02 Known fungi that cause damage to $C$. orbiculatus within its native range.

1.03 Known arthropods that cause damage to $C$. orbiculatus within its native range.

7

Chapter 2: Effects of high levels varying herbicide and surfactant levels on understory $C$. orbiculatus plants

2.01 Average stem diameter and aboveground volume for understory plants by site. 31

2.02 Treatments with breakdown of volume to volume constituents.

2.03 Environmental conditions at time of application.

2.04 List of Explanatory Variables and Levels.

2.05 Attribute damage categories (response variables) with descriptions and photos. 35

2.06 P-Values for MANOVA Testing.

2.07 P-values for ANOVA testing for each attribute $(\mathrm{N}=160)$.

2.08 Site Comparisons.

41

2.09 Average week of first appearance by attribute. 


\section{Preface}

On February $3^{\text {rd }}, 1999$ the Executive Order on Invasive Species (E. O. 13112, 1999) was signed by President Bill Clinton, creating the National Invasive Species Council (NISC) while also defining an "invasive species" as an alien species whose introduction does or is likely to cause economic or environmental harm, or harm to human health. Approximately $65 \%$ of the 2,100 recognized weed species, or species that negatively interfere with crop production or other uses of land, in the United States are nonnative (FICMNEW and Westbrooks, 1998).

Dale Bosworth, Chief of the USDA Forest Service, labeled invasive species, along with fire and fuels, loss of open space, and unmanaged recreation, as one of the four major threats to the health of the United States forests and grasslands (Sexton et al., 2006). Species spread has historically been regulated by environmental barriers and conditions. The advent of global commerce and the progress of human culture have drastically elevated the movement of different species to a global level (Chornesky and Randall, 2003).

With the movement and spread of species no longer regulated by traditional environmental and geophysical barriers, there are opportunities for species to proliferate and thrive in lands in which there are no native natural enemies that have evolved the attributes to keep the invading species in check (Mooney and Cleland, 2001). Invasive species are a major threat to the health of forested land, which makes up a majority of the Appalachian mountain region (FICMNEW and Westbrooks, 1998). 
Chapter 1: Literature Review: Celastrus orbiculatus a concern in the Appalachian Region

\section{A. Introduction}

Invasive species negatively impact an ecosystem by physically competing with native species for growing space (Wardle et al., 1994). Competition may reduce the ability of native species to increase or even maintain population size (Huenneke and Thompson, 1995). Invasive species may indirectly impact other life in the ecosystem by replacing native species that are essential for the survival of other species (food, shelter, etc.).

Many invasive species share the same attributes of early-successional plant species such as abundant seed production, small seed-size, rapid growth, and quick establishment abilities (Rajmanek and Richardson, 1996). These attributes allow for species to quickly dominate any open space and monopolize growing space and nutrients. Native early-successional species are not generally found in closed-canopy, forested areas, apart from the seed bank or in response to canopy openings (Huebner, 2003). Natural forested areas in the Appalachian region have evolved and adapted to out-compete these early successional species effectively eliminating them as a problem to an intact forest. In their native range, species develop attributes that aid in their competitiveness to help them survive. Often times, when introduced to a new land, these attributes allow for a species to not only survive, but thrive.

Oriental bittersweet is one such plant that can survive and thrive in Appalachian forest ecosystems. In its native land, it is not considered a pest (Hou, 1955), but in its introduced range, it has really taken a negative toll on natural ecosystems (Patterson, 1974; McNab and Meeker, 1987; Dreyer, 1984). Bittersweet, due to its prolific seed production, lack of natural enemies, and shade tolerant growth patterns, has become a major naturalized pest in forested areas of the eastern United States (McNab and Meeker, 1987). 


\section{Celastrus orbiculatus Thunb.}

Celastrus orbiculatus Thunb. is a common invasive plant species across much of the Eastern United States (Fig 1.01) and is considered an invasive pest or exotic species that detrimental to humans or human concerns, in much of the northeastern United States (Swearingen et al., 2010). It is known by common names such as false, oriental, and Asiatic bittersweet, and climbing spindle berry. C. orbiculatus was introduced in the mid 1860's from East Asia, including North and central Japan, Korea, and China north of the Yangtze River (Hou, 1955). The adapted range in the United States has been broadened considerably due to its attractive display of mature fruits, relative ease of cultivation, and resistance to insect and disease, which have led to its popularity and availability as a nursery plant over much of the United States (McNab and Meeker, 1987; White and Bowden, 1946). It is prized as an ornamental decorative plant often used in winter floral arrangements (Leicht-Young et al., 2007).

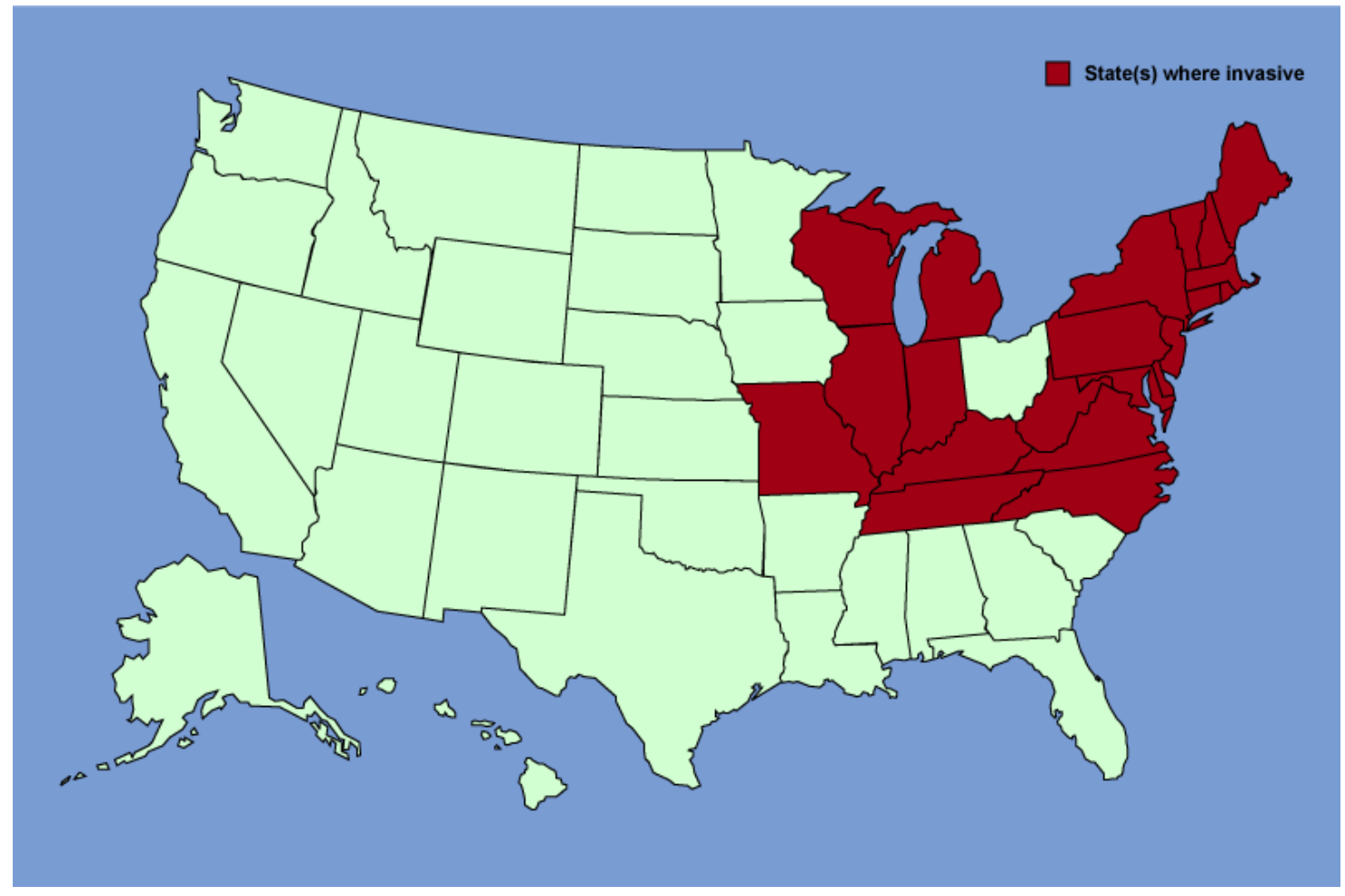

Figure 1.01 - States where C. orbiculatus is considered invasive (Swearingen, J. Asian Bittersweet; Asiatic Bittersweet; Oriental Bittersweet. Digital image.Plant Conservation Alliance Alien Plant Working Group. Web. <http://www.nps.gov/plants/alien/map/ceor1.htm>. 
Often associated with old home sites, C. orbiculatus can easily escape cultivated gardens and become established in disturbed sites along hedgerows, roads, woodland edges, and salt marshes (McNab and Meeker, 1987). C. orbiculatus is very successful in colonizing new areas due to its bountiful seed crop and ability to root sprout, as well as its plastic growth patterns and adaptability (Greenberg et al., 2001). Once established, its aggressive growth patterns allow the plant to dominate and take over a site. C. orbiculatus works quickly to monopolize nutrients and light by growing up and over surrounding vegetation effectively smothering previously dominant plants (Ellsworth et al., 2004). C. orbiculatus is listed as a Category 1: highly invasive weed in both the Eastern and Southern Region of the U.S. Forest Service (Uva et al., 1997; SEEPPC, 2003).

\section{B. Taxonomy and Description}

Celastrus orbiculatus Thunb. is a vine in the Celastraceae (Stafftree) family. Celastraceae is a mostly tropical and sub-tropical family comprising of about 55 genera of woody vines, shrubs and trees (Simmons et al. 2008). C. orbiculatus exists as a woody deciduous perennial climbing, twining vine sometimes occurring as a small trailing shrub (McNab and Meeker, 1987). Stems of older plants can reach up to four inches in diameter. The branches are round, glabrous or smooth, and light to dark brown (Leicht-Young et al., 2007). Younger stems exhibit noticeable lenticels. Leaves of $C$. orbiculatus are alternate and semi-ovate or elliptical with finely toothed margins. The round leaves are greenish to yellow and vary in size from $2-12 \mathrm{~cm}$ long to $1.5-8$ cm wide (Bergmann and Swearingen, 1999; Leicht-Young et al., 2007).

There is a native cousin to C. orbiculatus, American bittersweet (Celastrus scandens), which has a range from the east coast of the United States to as far west as Wyoming (Pooler et al., 2002). Both species can occur in the same habitat and can hybridize (Pooler et al., 2002; Leicht-Young et al., 2007). The most definitive way of distinguishing between the plants is their fruiting habits. C. scandens produces flowers and fruits in terminal panicles, while $C$. orbiculatus produces flowers and fruits in multiple leaf axils all along the stem, however, this method is useful for distinguishing only female plants (Leicht-Young et al., 2007). Another method that is useful is determining the color of the pollen in male flowers. Pollen of male $C$. scandens flowers 
will appear yellow, while pollen of male $C$. orbiculatus flowers will appear white. Leaf-out traits are another method useful in distinguishing the two species (Pavlovic et al., 2007). The leaves of $C$. orbiculatus are conduplicate, meaning that the leaves are folded against each other. The leaves of $C$. scandens are involute, meaning that leaf margins are rolled in like a scroll (Table 1.01)

Table 1.01 Useful traits for distinguishing C. scandens from C. orbiculatus.

\begin{tabular}{|c|c|c|}
\hline Distinguishing Trait & Celastrus scandens & Celastrus orbiculatus \\
\hline $\begin{array}{l}\text { Fruit and Flower } \\
\text { Locations }\end{array}$ & $\begin{array}{l}\text { Flowers on female plant occur in } \\
\text { small clusters at the terminal } \\
\text { pannicle of the stem. Fruits are } \\
\text { bright yellow. }\end{array}$ & $\begin{array}{l}\text { Flowers on female plant occur } \\
\text { in small axillary clusters all } \\
\text { along the stem. Fruits are } \\
\text { orange. }\end{array}$ \\
\hline $\begin{array}{l}\text { Pollen Color of Male } \\
\text { Flowers }\end{array}$ & Pollen of male flowers is yellow & $\begin{array}{l}\text { Pollen of male flowers is } \\
\text { white }\end{array}$ \\
\hline $\begin{array}{l}\text { Posture of leaves at leaf- } \\
\text { out of first buds }\end{array}$ & $\begin{array}{l}\text { Upon leaf-out, the leaves are } \\
\text { involute, or rolled like a scroll and } \\
\text { expand out from the center. }\end{array}$ & $\begin{array}{l}\text { Expanding leaves at leaf-out } \\
\text { conduplicate, or folded } \\
\text { together like a book. }\end{array}$ \\
\hline
\end{tabular}

\section{Silvics}

Once established, $C$. orbiculatus exhibits extremely fast and aggressive growth patterns, often exceeding 3m of growth in one growing season (Patterson, 1974; McNab and Meeker, 1987, Ellsworth et al., 2004). C. orbiculatus twists and twines up the trunks of trees eventually reaching the canopy. Once in the canopy, the plant grows out and over the canopy smothering the crown of affected trees (Patterson, 1974; Dreyer et al. 1987; McNab and Meeker, 1987). Affected trees suffer from loss of vigor due to shading and the constriction and smothering ability of the plant presents a large threat to affected trees and other vegetation. Constriction by bittersweet disrupts the downward movement of organic materials through the plant which, over time, can cause health issues and physical deformities to the bole of the tree (Figures 1.02 and 1.03; Lutz, 1943). 

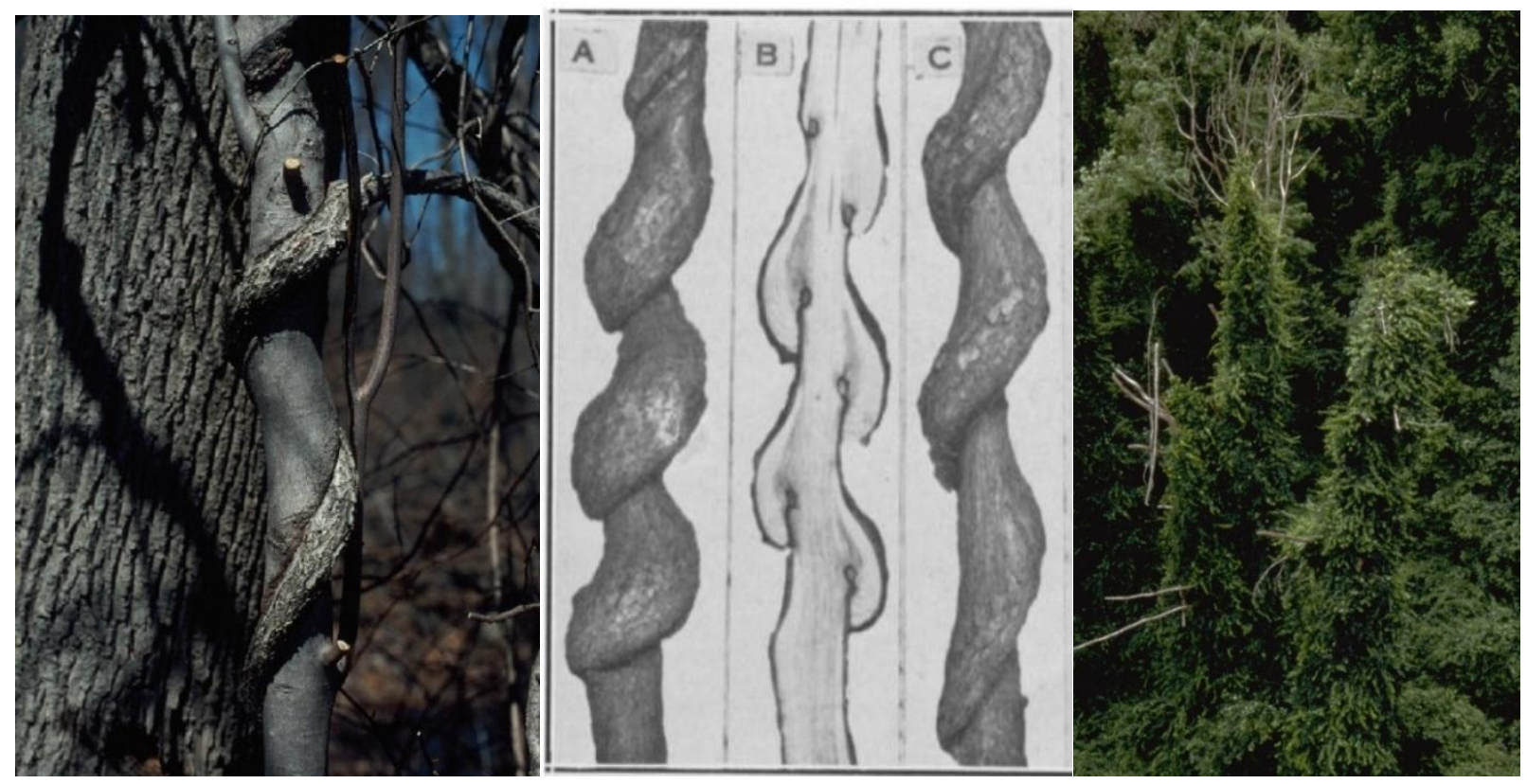

Figure. 1.02 C. orbiculatus stem growth pattern inhibiting growth of affected tree (Leslie J. Mehrhoff, University of Connecticut, Bugwood.org); Figure 1.03 Constriction from Celastrus vine leads to abnormal growth in bole of Sassafras (Lutz 1943); Figure 1.04 C. orbiculatus covering edge trees near Ashville, NC (Max Williamson, USDA Forest Service, Bugwood.org).

Young stands, mainly consisting of seedlings to pole-sized timber, are most susceptible to the effects of C. orbiculatus (McNab and Meeker, 1987). If the invasive plant is present in the understory of a recently released stand, $C$. orbiculatus is able to survive at light levels as low as $2 \%$ full sun and quickly respond to changes in light intensities and can even overtop 1-2m tall vegetation by the end of a single growing season (Ellsworth et al., 2004). It can expand its foothold in the stand by root suckering and consequentially can out-compete the regeneration of desired species.

\section{Problems}

C. orbiculatus is quite successful in colonizing sparsely populated ecological niches. Part of the reason is the large amount of seeds produced by the plant (Greenburg et al. 2001). Apart from increasing silvicultural problems and threatening biodiversity in native habitats in the United States, $C$. orbiculatus offers a severe threat to the native, American bittersweet ( $C$. scandens). $C$. scandens does not have as wide a range of ecological tolerances as $C$. orbiculatus and their 
habitats overlap (Pooler et al., 2002). C. orbiculatus presents a severe threat to the further existence of American bittersweet by out-competing the native species for resources. Over a two-year study, Leicht-Young et al. (2007) compared above ground growth (biomass and height) and mortality between $C$. scandens and $C$. orbiculatus across sites that varied greatly in soil moisture and light penetration. They found $C$. orbiculatus to perform much better in mesic soil conditions associated with forested sites. C. orbiculatus exhibits a much higher fecundity and it also has expressed the ability to hybridize with $C$. scandens. The resulting hybrid has been shown to exhibit the aggressive characteristics more similar to $C$. orbiculatus (Pooler et al., 2002).

\section{E. Site}

Disturbed sites are most susceptible to the invasion of $\mathrm{C}$. orbiculatus (McNab and Meeker, 1987). Areas where growing space such as light, soil nutrients and water are readily available are prime habitats for colonization by bittersweet. Though these areas may be fertile grounds for an invasive species, they have to be exposed to seeds from the plant. Animals and humans play a big role in the dispersal of the seeds. Though the main habitat for $C$. orbiculatus is disturbed sites along forest edges and open land, undisturbed intact forests are also at risk to invasion (Greenburg et al., 2001; Ellsworth et al., 2004). Mesic mixed-hardwood eastern forests are the most common habitat (Robertson et al., 1994). C. orbiculatus can grow to dominate a site in a relative short number of years and can form dense complexes with other vine species (Fike and Niering, 1999). Seedlings appear in the spring and along with older seedlings, may grow to reach a peak site density of 60 stems $/ \mathrm{m}^{2}$ followed by a decline in density, most likely due to drought, as the growing season continues (Patterson, 1974).

Pande et al. (2007) developed a prediction model for the occurrence of $C$. orbiculatus in Southern Illinois. The model focused on environmental factors recorded in areas invaded by $C$. orbiculatus and adjacent areas. Significant environmental factors associated with the presence or absence of $C$. orbiculatus included presence of oak, elevation, slope gradient, soil pH, soil texture, and distance to nearest road. The probability of occurrence was highest $(85 \%$ correct 
prediction) on gently sloping interfluves, or areas of raised land dividing two river valleys, with successional forest canopy not dominated by oak.

\section{F. Pathogens and Natural Enemies}

Records on pathogens and natural enemies of $\mathrm{C}$. orbiculatus are not extensive. There are only three fungal species known to infect the plant in its native range (Table 1.02). Of the three ascomycete fungi, only Uncinula sengokui is host specific. C. orbiculatus has no known biological controls in North America. In its native range in Korea, C. orbiculatus has been found to be a host for a leaf spot fungus and a powdery mildew (Lee at al. 1983). Additionally, only six arthropod species (Table 1.03) are known to cause damage to C. orbiculatus (Fanglan, 1979; Zheng et al. 2006). There are no known pathogens or natural enemies of $C$. orbiculatus native to North America.

Table 1.02 - Known fungi that cause damage to $C$. orbiculatus within its native range.

\begin{tabular}{lll}
\hline Phylum & Family & Species \\
\hline Ascomycota & Erysiphaceae & Microsphaera celastri Y.N. Yu \& Y.Q. Lai \\
& & Uncinula sengokui E.S. Salmon \\
& Meliolaceae & Amazonia celastri Y.X. Hu \& B. Song \\
\hline
\end{tabular}

Table 1.03 - Known arthropods that cause damage to $C$. orbiculatus within its native range.

\begin{tabular}{lll}
\hline Order & Family & Species \\
\hline Coleoptera & Scolytidae & Hypothenemus eruditus Westwood \\
Hemiptera & Coreidae & Plinachtus bicoloripes Scott \\
Homoptera & Aphidae & Aphis clerodendri Matsumura \\
& Diaspididae & Unaspis euonymi (Comstock) \\
& Triozidae & Trioza cealstrae Li \\
Lepidoptera & Yponomeutidae & Ypoomeuta sociatus Moriuti \\
\hline
\end{tabular}

\section{G. Reproduction and Propagation}

C. orbiculatus is dioecious, exhibiting separate female (fruiting) and male (non-fruiting) plants. Fruiting plants produce clusters of small green flowers in axillary clusters (Zheng et al., 2006; Leicht-Young et al., 2007). C. orbiculatus has shown high fecundity as an annual fruit bearer. Plants will produce flowers as soon as its second year, while $C$. scandens will take four to five 
years to produce flowers (Wyman, 1950). C. orbiculatus spreads vigorously on site through root suckering and can proliferate quickly under a variety of site conditions (Edminster and May, 1951; Leicht-Young et al., 2007).

The prolific display of flashy fruits exhibited by $C$. orbiculatus attracts a wide range of fructiferous animals. Animals, especially birds, are mobile and have the ability to travel great distances aiding in the spread of C. orbiculatus from site to site (Dreyer et al., 1987; Mehrhoff, 1986). This is a leading cause of exposure of new seeds to disturbed sites along fencerows, woodland edges, and beneath power lines (Brizicky, 1964; Wendel, 1974). Once deposited, C. orbiculatus has a high rate of germination (Patterson 1974; Dreyer et al., 1987; Clement et al., 1991). Once established, C. orbiculatus has been shown to spread vigorously through the use of root suckers (Dreyer, 1984; Dreyer et al., 1987; McNab and Meeker, 1987; Patterson, 1974). This clonal spread, in addition to high seed production, can lead to the establishment of dense thickets that monopolize available growing space and help prevent the establishment of natural species.

Humans also play major role in the spread of the plant. C. orbiculatus is highly desired as a nursery plant due its flashy red berries and its ease cultivation (Dirr, 1983; Pooler et al., 2002). Since its introduction to North America in the 1860's, cultivation of the plant has helped to increase its range to 33 states by 1974 (Patterson, 1974; McNab and Loftis, 2002).

\section{H. Invasive Properties}

C. orbiculatus is a very persistent and fast growing plant. An aggressive root system allows bittersweet to spread through vegetative means, quickly taking over a site (Dreyer 1984; McNab and Meeker 1987). Seeds germinate best in partial to dense shade which allows bittersweet to become established in forested areas. Ellsworth et al. (2004) showed that seedlings could germinate, survive and growth at light levels as low as $2 \%$ direct sunlight. Also, as sunlight levels increase, plants were shown to increase leaf ratio to biomass. Plants were able to quickly increase photosynthesis when exposed to intense light leading to quick growth responses to available light freed up during over story disturbances, such as tree fall or overstory removal, suggesting that established understory populations should be controlled 
before harvesting. $C$. orbiculatus was shown to affect soil $\mathrm{pH}$ of invaded areas which may have an impact on the reintroduction of native plants to an invaded ecosystem (Leicht-Young et al., 2009).

Bittersweet has the ability to climb all sorts of supports from trees to power lines, to buildings (Dreyer 1987, Putz 1995). C. orbiculatus may spread rapidly and with proper disturbance of landscape, may become the dominant canopy species (Silveri et al. 2001).

\section{Possible uses}

Studies have been carried out to find possible medical uses for $C$. orbiculatus and its derivatives. Kim et al. (1998 and 1999) isolated a sesquiterpene ester from the root of $C$. orbiculatus that was shown to reverse multidrug resistance in cancer cells. Jin et al (2002) found that the same sesquiterpene esters exhibited anti-inflammatory properties by inhibiting NF-KB activation and nitric oxide production. Xu et al, (2008) found that similar sesquiterpenoids isolated from celastrus exhibited cytotoxicity in human melanoma and cervical carcinoma cells. Basing their study on the role of $C$. orbiculatus in folk medicine as a treatment for rheumatoid arthritis and bacterial infections, Hwang et al (2001) found moderately active antioxidant and antibacterial properties from a benzoylated Flavan-3-ol glycoside extracted from the aerial portions of the plant. These same sesquiterpene compounds extracted from the roots of $C$. orbiculatus and other members of the Celastraceae family were also found to exhibit insect anti-feeding properties (Gonzalez et al., 1997). Traditional Chinese agriculture included various members of the Celastraceae family to be planted to protect desired crops from insect attack (Swingle et al., 1941).

Otani et al. (1991) found that some enzymes produced by C. orbiculatus leaves have value in milk curdling. These enzymes might be used as an alternative to calf rennet enzymes that are traditionally used in the process of cheese production.

In Japan, C. orbiculatus is planted as a hedge. In the United States, it is readily available as a commercial plant and is harvested for its ornamental values (Hou, 1955; McNab and Meeker, 1987). It is often valued for its flashy fall fruits. In the past, C. orbiculatus has been planted for 
erosion control in highway and conservation plantings. Native alternatives include American bittersweet (C. scandens), trumpet honeysuckle (Lonicera sempervirens, Caprifoliaceae), trumpet creeper (Campsis radicans, Bignoniaceae), passionflower vine (Passiflora lutea, Passifloraceae), Dutchman's pipe (Aristolochia macrophylla, Aristolochiaceae), and native wisteria (Wisteria frutescens, Fabaceae) (Bergmann and Swearingen, 1999).

\section{J. Control}

The most efficient method of managing invasive species is to prevent their spread and invasion (Sheley et al., 1999). This goal can be obtained by limiting disturbance (Lozon and Maclsaac, 1997; McNab and Loftis, 2002) on pristine land and maintaining natural communities and by keeping a watchful eye through land surveys (Leung et al., 2005). Monitoring should be focused on likely sources of $C$. orbiculatus introduction, such as bare soils, old fields, woodlands and waterways. Ellsworth et al. (2004) showed a strong correlation between seed rain and seedling emergence. This combined with a low seed bank emergence ( 1 seedling $\mathrm{m}^{-2}$ ) suggests that eradication of seedling advance regeneration and adult plants prior to seed rain may contribute as an effective control strategy.

Management of $C$. orbiculatus, as with many other invasive plant species, requires a combination of extensive monitoring and surveying pre and post control (URI). Cutting, mowing, and grubbing can be used to control small populations of $C$. orbiculatus (Bergmann and Swearingen, 1999; IPSAWG, 2006). Sprouts may occur if roots are not completely removed during grubbing. Treatments must be applied often enough to prevent regrowth, usually two week intervals are good. Less frequent treatments seem to encourage sprouting. Climbing vines should be cut as close to the ground as possible.

Chemical herbicides can be used as an initial control for a new or severe unwanted plant infestation. Used by themselves, herbicides do not provide long term control (Bussan and Dyer, 1999). Herbicides do not change the conditions in which the invasion has occurred; they only postpone the eventual invasion. Systemic herbicides work from the application area to move through and control the whole plant. 
Triclopyr ([(3,5,6-Trichloro-2-pyridinyl)oxy]acetic acid) is a systemic herbicide that is currently registered for use on rice, pasture and rangeland, rights-of-way, forests and lawn. First registered in 1979, it is a synthetic auxin, meaning it mimics the effects of the plant hormone auxin (indole acetic acid), and when applied at effective doses, causes disorganized and uncontrolled plant growth which eventually leads to the plant's death (Tu et al., 2001). Administration in low doses can lead to uncontrolled cell growth and division which eventually leads to the destruction of plant vascular tissue. Triclopyr is a selective herbicide meaning that its mode of action is only effective on broadleaf herbs and woody plants and is ineffective against grasses and other monocots (WSA, 1994; NPIC, 2002). Name brand products that contain triclopyr include Garlon ${ }^{\circledR}$, Turflon $^{\circledR}$, Pathfinder $^{\circledR}$, Access $^{\circledR}$, Brush-B-Gon $^{\circledR}$, Confront $^{\circledR}$, Crossbow $^{\circledR}$ (Tu et al., 2001; NPIC, 2002).

Glyphosate ( $\mathrm{N}$-(phosphonomethyl)glycine) is a systemic herbicide that damages most vegetation with which it comes in contact. This "broad-spectrum" herbicide was first registered for use in the United States in 1974 for use in agriculture and forestry, lawns and gardens, and industrial areas (NPIC, 2010). Available in many forms and found in over 750 products, glyphosate is effective in the control of many grasses, forbs, shrubs, vines, and trees (Tu et al., 2001; NPIC, 2010). Popular products that contain glyphosate include, Roundup Ultra ${ }^{\circledR}$, Roundup Pro $^{\circledR}$, Accord $^{\circledR}$, Accord Concentrate $^{\circledR}$, Honcho $^{\circledR}$, Pondmaster $^{\circledR}$, Protocol $^{\circledR}$, Rascal $^{\circledR}$ and many more (Tu et al., 2001).

Glyphosate is applied directly to plant foliage and when used in smaller quantities, it can act as a plant growth regulator (Baylis, 2000). Glyphosate kills plants by inhibiting the activity of the enzyme 5-enolpyruvylshikimic acid-3-phosphate (EPSP) synthase which results in the accumulation of shikimate-3-phosphate, which eventually blocks the production of aromatic amino acids that help form important proteins and link primary and secondary metabolism (Carlisle and Trevors, 1988). Plants treated with glyphosate continue to grow until stored amino acids are used up resulting in delayed symptom expression. For this reason, glyphosate is considered to be slow-acting (Baylis, 2000). Though EPSP synthase is the only known enzyme target of glyphosate, it affects many physiochemical and physiological processes such as 
reduction in photosynthesis and degradation of chlorophyll (Siehl, 1997; Cole, 1985). The combined modes of action result in familiar symptoms of phytotoxicity such as chlorosis, stunting, and reduction in apical dominance (Baylis, 2000).

Literature for the control methods for $C$. orbiculatus is often in the form of fact sheets and weed-control reference books similar to Bergman and Swearingen (1999), Dreyer (1994), Greenbuerg et al. (2001), Hutchinson (1992), Miller (2002), and Southeast Exotic Pest Plant Council Invasive Plant Manual (2003). Recommended chemical control for C. orbiculatus varies by type of infestation. For heavy infestation of larger plants that have grown high up into the canopy and where foliage cannot be reached, basal bark application of systemic herbicides can be effective. A $20 \%$ triclopyr or glyphosate-based herbicide solution mixed with basal oil, diesel fuel, or kerosene and a penetrant can be applied to the bottom 16 inches of stems (Hoyle, 2004; Miller et al., 2010; Swearingen et al., 2010). The cut stem method may also be effective for this large plant infestation where a $25 \%$ solution of systemic herbicide may be applied to the fresh cut stem of the bittersweet plant (Hoyle, 2004; Miller et al., 2010; Swearingen et al., 2010). For smaller plants, when leaves are present, a foliar application of $2-4 \%$ herbicide and 0.5\% surfactant is sufficient (Hoyle, 2004; Miller et al., 2010; Swearingen et al., 2010).

Integrated management is often an effective option for many unwanted plant species. Integrated management calls for the effective combination of various methods that work together to control the target species (Portland Parks and Recreation, 2012). These methods may include chemical control combined with cultural, biological, mechanical or manual control as well as planting alternative species. The goal is to minimize detrimental environmental impact that results from the use of chemical pesticides. 


\section{K. Literature Cited}

Baylis, A.D. (2000). Why glyphosate is a global herbicide: strengths, weaknesses, and prospects. Pest Manag Sci. 56. p299-308.

Bergmann, C., and J. M. Swearingen. (1999). Fact sheet: Oriental bittersweet--Celastrus orbiculatus Thunb. Weeds gone wild: Alien plant invaders of natural areas. The Plant Conservation Alliance's Alien Plant Working Group (Producer). February 20, 2011 <http://www.nps.gov/plants/alien/fact/ceor1.htm>

Brizicky, G. K. (1964). The genera of Celastrales in the southeastern United States. J. Arnold Arbor. 45. p206-234.

Bussan, A. J., W. E. Dyer. (1999). Herbicides and rangeland. In: Sheley, R. L., and J.K. Petroff, eds. Biology and management of noxious rangeland weeds. Corvallis, OR: Oregon State University Press: p116-132.

Carlisle, S. M., and J. T. Trevors. (1988). Glyphosate in the environment. Water Air Soil Pollution. 39. p409-420.

Chornesky, E. A., and J. M. Randall. (2003) The threat of invasive alien species to biological diversity: setting a future course. Annals of the Missouri Botanical Garden 90:1. p 67-76. Retrieved February 23, 2012 from JSTOR. Web. <http://www.jstor.org/stable/3298527 .>

Clement, C. R.; R. S. Warren; G. D. Dreyer; P. T. Barnes. (1991). Photosynthesis, water relations, and fecundity in the woody vines American and oriental bittersweet (Celastrus scandens and $C$. orbiculatus). Annual meeting of the Botanical Society of America, August 4-8; San Antonio, TX. American Journal of Botany. 78:6 p134. Poster paper.

Cole, D.J. (1985). Mode of action of glyphosate - a literature analysis, in The Herbicide Glyphosate, ed by Grossbard, E. and Atkinson, D. Butterworths, London. pp 48-74.

Dirr, M.A. (1983). Manual of Woody Landscape Plants. Stipes Publishing Co.,Champaign, IL. p.826

Dreyer, G. D. (1984). Spontaneous naturalization of woody plants in the Connecticut arboretum-II. Newsletter Conn. Bot. Soc. 12:3. p 2.

Dreyer, G. D.; L. M. Baird, and C. Fickler. (1987). Celastrus Scandens and Celastrus Orbiculatus: comparisons of reproductive potential between a native and an introduced woody vine. Bulletin of the Torrey Botanical Club. 114:3 p260-64. Retrieved February 14, 2001 from JSTOR. Web. <http://www.jstor.org/stable/2996463>. 
Dreyer, G.D. (1994). Element Stewardship Abstract for Celastrus orbiculatus. The Nature Conservancy.

Edminster, F. C. and R. M. May (1951). Shrub plantings for soil conservation and wildlife cover in the Northeast. USDA Soil Conservation Service Circular No. 887.

Ellsworth, J. W.; R. A. Harrington and J. H. Fownes.(2004). Survival, growth and gas exchange of Celastrus orbiculatus seedlings in sun and shade. The American Midland Naturalist Journal. 151. p233-40.

Exec. Order No. 13112, 3 C.F.R. 6183 (1999). Print.

Fanglan, D. (1979). Sylloge Fungorum Sinicorum. Science Press. Beijing, China. p . 1527.

Federal Interagency Committee for the Management of Noxious and Exotic Weeds (FICMNEW) and R. G. Westbrooks (1998). Invasive Plants: Changing the Landscape of America. All U.S. Government Documents (Utah Regional Depository). Paper 490.

Fike, J. and W. A. Niering. (1999). Four decades of old field vegetation development and the role of Celastrus orbiculatus in the northeastern United States. Journal of Vegetation Science. 10:4. p 483-92.

Gonzalez, A. G.; I. A. Jimenez; A. G. Ravelo; J. Coll; J. A. Gonzalez and J. Lloria. (1997). Antifeedant activity of sesquiterpenes from Celastraceae. Biochemical Systematics and Ecology. 25:6. p 513-19.

Greenberg, C. H.; L. M. Smith, and D. J. Levey, (2001). Fruit fate, seed germination and growth of an invasive vine--an experimental test of 'sit and wait' strategy. Biological Invasions. 3:4. p 363-72.

Hou, D. (1955). A revision of the genus Celastrus. Annals of the Missouri Botanical Garden. 42: 215. p 302.

Hoyle, Z. (2004). Oriental bittersweet: a patient invader. News Releases from the Southern Research Station.

Huebner, C. D. (2003). Vulnerability of oak-dominated forests in West Virginia to invasive exotic plants: temporal and spatial patterns of nine exotic species using herbarium records and land classification data. Castanea. 68:1. p1-14.

Huenneke, L. F., and J. K. Thomson. (1995). Potential interference between a threatened endemic thistle and an invasive nonnative plant. Conservation Biology. 9. p416-25. 
Hutchison, M. (1992). Vegetation management guideline: round-leaved bittersweet (Celastrus orbiculatus Thunb.) Natural Areas Journal. 12:3. p161.

Hwang, B. Y.; H. S. Kim, J. H. Lee, Y. S. Hong, J. S. Ro, K. S. Lee, and J. J. Lee (2001). Antioxidant benzoylated flavan-3-ol glycoside from Celastrus orbiculatus. Journal of Natural Products. 64:1. p82-4.

IPSAWG - Invasive Plant Species Assesment Working Group.(2006). Invasive plants species fact sheet: oriental bittersweet Celastrus orbiculatus. IPSAWG - Invasive Plant Species Assesment Working Group. Print.

Jin, H. Z.; B. Y.Hwang, H. S. Kim, J. H. Lee, Y. H. Kim, and J. J. Lee. (2002). Anti-inflammatory constituents of Celastrus orbiculatus inhibit the NF-kB activation and NO production. Journal of Natural Products. 65:1. p89-91.

Kim, S. E.; Y. H. Kim, J. J. Lee, and Y. C. Kim. (1998). A new sesquiterpene ester from Celastrus orbiculatus reversing multidrug resistance in cancer cells. Journal of Natural Products. 61:1. p108-111.

Kim, S. E.; H. S. Kim, Y. S. Hong, Y.C. Kim, and J. J. Lee. (1999). Sesquiterpene esters from Celastrus orbiculatus and their structure--activity relationship on the modulation of multidrug resistance. Journal of Natural Products. 62:5. p697-700.

Lee, C. K., K. H. Kim, C. K. Yi. (1983). Unrecorded host plants of powdery mildew in Korea. Jour. Koreans For. Soc. 60. p 1-9.

Leicht-Young, S. A., J. A. Silander Jr and A. M. Latimer. (2007). Comparative performance of invasive and native Celastrus species across environmental gradients. Oecologia. 154. p273-82. SpringerLink. Web. 8 Feb. 2011.

Leicht-Young, S. A., H. O’Donnell, A. M. Latimer, and J A Silander Jr. (2009). Effects of an invasive plant species, Celastrus orbiculatus, on soil composition and processes. The American Midland Naturalist. 161:2. p219-31.

Leung, B.; D. Finnoff, J. F. Shogren, and D. Lodge. (2005). Managing invasive species: rules of thumb for rapid assessment. Ecological Economics. 55. p24-36.

Lozon, J.D. and H.J. Maclsaac. (1997). Biological invasions: are they dependent on disturbance?. Envionr. Res. 5. p131-144.

Lutz, H. J. (1943). Injuries to Trees Caused by Celastrus and Vitis. Bulletin of the Torrey Botanical Club. 70:4. p436-39. JSTOR. Web. 9 Feb. 2011. <http://www.jstor.org/stable/2481567>. 
McNab, W. H., and M. Meeker. (1987). Oriental bittersweet: a growing threat to hardwood silviculture in the Appalachians. Northern Journal of Applied Forestry. 4:4. p174-77. IngentaConnect. Web. 14 Feb. 2011.

McNab, W. H., and D. L. Loftis. (2002). Probability of occurance and habitat features for oriental bittersweet in an oak forest in the southern Appalachian mountains, USA. Forest Ecology and Management. 155. p45-54.

Mehrhoff, L. J. (1986). Notes on the Connecticut flora - IV. The genus Celastrus (Celastraceae) in Connecticut. Newsletter of the Connecticut Botanical Society. 14:1. p 4-5.

Miller, J.H. (2002). Exotic pest plants and their control. The Bugwood Network. http://www.bugwood.org/weeds/forestexotics.html.

Miller, J.H., E.B. Chambliss and N.J. Loewenstein. (2010). A field guide for the identification of invasive plants in southern forests. General Technical Report SRS-119. Asheville, NC. United States Department of Agriculture, Forest Service. p. 126.

Mooney, H. A. and E. E. Cleland. (2001). The evolutionary impact of invasive species. Proceedings of the National Academy of Sciences. 98:10. p 5446-5451.

NPIC - National Pesticide Information Center. Glyphosate general fact sheet. Sept. 2010. Web. <http://npic.orst.edu/factsheets/glyphogen.pdf>.

NPIC - National Pesticide Information Center. Triclopyr general fact sheet. NPIC. Sept. 2002. Web. <http://npic.orst.edu/factsheets/triclogen.pdf>.

Otani, H., M. Iwagaki, and A. Hosono. (1991). The screening of trees having milk clotting activity. Animal Science and Technology. 62:5. p417-423.

Pande, A., C. L. Williams, C. L. Lant, and D. J. Gibson. (2007). Using map algebra to determine the mesoscale distribution of invasive plants: the case of Celastrus orbiculatus in southern Illinois, USA. Biol Invasions. 9. p419-31.

Patterson D. T. (1974). The ecology of oriental bittersweet, a weedy introduced ornamental vine. Ph.D. Diss., Duke Univ., Durham, NC.

Pavlovic, N. B., S. Leicht-Young, R. Grundel, and K. J. Frohnapple. (2007). American and Oriental Bittersweet identification. GLSC Fact Sheet 2007-2. U.S. Department of the Interior. U.S. Geological Survey. United States. 
Pooler, M. R., R. L. Dix, and J. Feely. (2002). Interspecific hybridizations between the native bittersweet, Celastrus scandens, and the introduced invasive species, C. orbiculatus.

Southeastern Naturalist. 1:1. p. 69-76. BioOne. Web.

Portland Parks and Recreation. (2012). Integrated Pest Management Program. Web. 10 March 2012.<http://www.portlandonline.com/parks/index.cfm?c=38296\&a=116237>.

Putz, F. E. (1995). Relay ascension of big trees by vines in Rock Creek Park, District of Columbia. Castanea. 60:2. p167-69.

Rajmanek M., and D.M. Richardson. (1996). What attributes make some plant species more invasive? Ecology. 77. p1655-1661.

Robertson, D. J., M. C. Roberston, and T. Tague. (1994). Colonization Dynamics of Four Exotic Plants in a Northern Piedmont Natural Area. Bulletin of the Torrey Botanical Club. 121:2. p10718. JSTOR. Web.

Sexton, T., J. Reaves, L. Payne, and A. Jeffers. Four Threats. US Forest Service: Four Threats. USDA Forest Service. Web. <http://www.fs.fed.us/projects/four-threats/>

Sheley, R. L., M. Manoukian, G. Marks. (1999). Preventing noxious weed invasion. In: Sheley, R. L.; Petroff, J.K., eds. Biology and management of noxious rangeland weeds. Corvallis, OR:

Oregon State University Press: p69-72.

Siehl, D.L. 1997. Inhibitors of EPSP synthase, glutamine synthase, and histidine synthesis. Rev Toxicol. 1. p37-67.

Silveri, A.; P. W. Dunwiddie, and H. J. Michaels. (2001). Logging and edaphic factors in the invasion of an Asian woody vine in a mesic North American forest. Biological Invasions. 3:4. p379-89.

Simmons, M. P. (2008). Phylogeny of the Celastreae (Celastraceae) and the relationships of Catha edulis (qat) inferred from morphological characters and nuclear and plastid genes. Molec. Phylogenet. Evol. 48. p745-57.

Southeast Exotic Pest Plant Council Invasive Plant Manual. (2003). http://www.fs.fed.us, 8 March 2012. U.S. Forest Service, Washington, D.C. 20250-0003 USA.

Swearingen, J., B. Slattery, K. Reshetiloff, and S. Zwicker. (2010). Plant Invaders of Mid-Atlantic Natural Areas, 4th ed. National Park Service and U.S. Fish and Wildlife Service. Washington, DC. Swingle, W. T., H. L. Hailer, E. H. Siegler, and M. C. Swingle. (1941). A Chinese insecticidal plant, Tripterigium wilfordii, introduced into the United States. Science. 93 p60-61. 
Tu, M., C. Hurd, and J. M. Randall. (2001). Triclopyr. Weed control methods handbook: tools and techniques for use in natural areas. P 7k.1 - 9

Uva, R.H., J.C. Neal, and J.M. DiTomaso. (1997). Weeds of the Northeast. Cornell University Press. Ithaca, New York.

Wardle, D. A., K. S. Nicholson, M. Ahmed, and A. Rahman. (1994). Interference effects of the invasive plant Carduusnutans L. against the nitrogen fixation ability of Trifolium repens L. Plant and Soil. 163. p287-97.

Wendel, G. W. (1974). Celastrus scandens L. P. 295-297 in Seeds of woody plants. USDA Forest Service Agricultural Handbook. 450

White, O. E., and W. M. Bowden. (1946). Oriental and American bittersweet hybrids. Journal of Heredity. 38:4. p125-28.

WSA. 1994. Herbicide Handbook. Weed Society of America. Champaign, Illinois, pp. 352.

Wyman, D. (1950). Fruiting habits of certain ornamental plants. Arnoldia: A continuation of the Bulletin of popular information of the Arnold Arboretum. Harvard University. 10:13. p81-85.

Xu, J., Y. Guo, X. Li, K. Wei, and X. Zhao. (2008). Cytotoxic Sesquiterpenoids from the Ethanol Extract of Fruits of Celastrus Orbiculatus. Journal of Ethnopharmacology. 117. p 175-77. ScienceDirect. Web. 20 Feb. 2011.

Zheng, H., Y.Wu, J. Sing, D. Binion, W. Fu, and R. Reardon. (2006). Invasive Plants of Asian Origin Established in the United States and Their Natural Enemies 2nd ed. Vol. 1. United States. USDA Forest Service. Forest Health Technology Enterprise. 


\section{Chapter 2: Effects of high rates of varying glyphosate and surfactant rates on understory Celastrus orbiculatus plants}

\section{A. Introduction}

Oriental bittersweet (C. orbiculatus) is an invasive climbing, twining vine that utilizes its surroundings to monopolize growing space. In non-forested settings, it is often found growing up any structure that it can twine around. In disturbed forested areas, where it can establish itself, it often grows up the base of trees and shrubs, physically damaging the boles and stems, eventually reaching the crowns effectively inhibiting growth and light exposure on affected plants (McNab and Meeker 1987; Lutz 1943). This non-native Celastrus species has created a major problem in native plant ecosystems.

Since $C$. orbiculatus is much more aggressive than the native $C$. scandens, it is beginning to take over the range of the native plant, threatening hybridization (Dreyer et al. 1987, Pooler et al. 2002). The vine's aggressive growth patterns and resiliency to traditional mechanical and manual control treatments, such as cutting the vines near the ground, and pulling or digging infestations, have become a major problem for forest management (McNab and Meeker 1987). When bittersweet climbs up into the canopy, physical damage results in the form of constricted growth of affected trees (Lutz, 1943).

Several control treatments have been suggested for $C$. orbiculatus. A combination of mechanical and chemical control in the form of cut stump or basal bark application of $20-25 \%$ systemic herbicides is often enough to control large specimens (IPSAWG, 2006; Swearingen et al. 2010). For infestations where a large portion of the plants exist as smaller plants in the understory, a foliar spray of a systemic herbicide at lower concentrations (2-4\%) mixed with a surfactant at $0.5 \%$ is recommended (IPSAWG, 2006; Swearingen et al., 2010).

While prescriptions for $C$. orbiculatus have been suggested, one local landowner made observations that standard foliar glyphosate treatments were not effective for the vine. This study was established to assess the validity of this claim and to explore the interaction of 
glyphosate and surfactant effects on the efficacy of bittersweet control. The goal was to assess whether standard rates of glyphosate were effective or if higher rates were necessary for sufficient control of smaller $C$. orbiculatus plants in the understory as well as to determine the effect of surfactant rate at varying rates. Other goals from this study included the creation of a timeline and key for the indicator attributes expressed by an understory $C$. orbiculatus plant in order to help applicators better understand the reactions of the plant to the treatments that they use. A better understanding of how a plant reacts to an herbicide treatment over time can help reduce sequential application of herbicides that are detrimental to the overall health of an ecosystem, which in turn can reduce overall cost on herbicide spending.

\section{B. Methods}

Four rates of glyphosate herbicide (Accord Concentrate ${ }^{\circledR}$ ) at $0 \%, 2.5 \%, 5 \%$, and $10 \%$, vol/vol were mixed with four rates of surfactant (Cide-Kick $\|^{\circledR}$ ) at $0 \%, 0.5 \%, 1 \%$, and $2 \%$ vol/vol in a factorial arrangement. Individual plants growing in a forest understory served as the experimental unit. Each treatment was replicated five times. The study was duplicated at 2 locations in northern West Virginia.

\section{i. Study Site History and Stand Structure}

Two sites were selected for this study (Fig 2.01). Both were selected based on the presence of a C. orbiculatus infestation. The first site was at the West Virginia University research forest and was located in a red pine plantation on a portion of Cooper's Rock State Forest in northwestern Preston County, West Virginia. The second site was located on private land owned by Mr. and Mrs. Brent Williams along the Tygart River near Colfax in southern Marion County, West Virginia. The WVU research forest site was located on a mountaintop ridge, while the Colfax site was located in a fertile river valley near the Tygart River.

Forest stand measurements help extract similarities and differences between sites. Stand structure was measured using a 0.04 hectare, fixed-area inventory plot (radius $11.35 \mathrm{~m}$ ) placed at the estimated center of each of the five replication blocks at each site. For each individual plot, tree distances from center were determined to the front of each tree using an Impulse 
laser. Plot- edge trees were checked to make sure that the center of the tree fell within the plot radius. For each tree, species and diameter at breast height (DBH) was measured to the nearest $\mathrm{cm}$. Trees were then separated into $5-\mathrm{cm}$ size classes. 


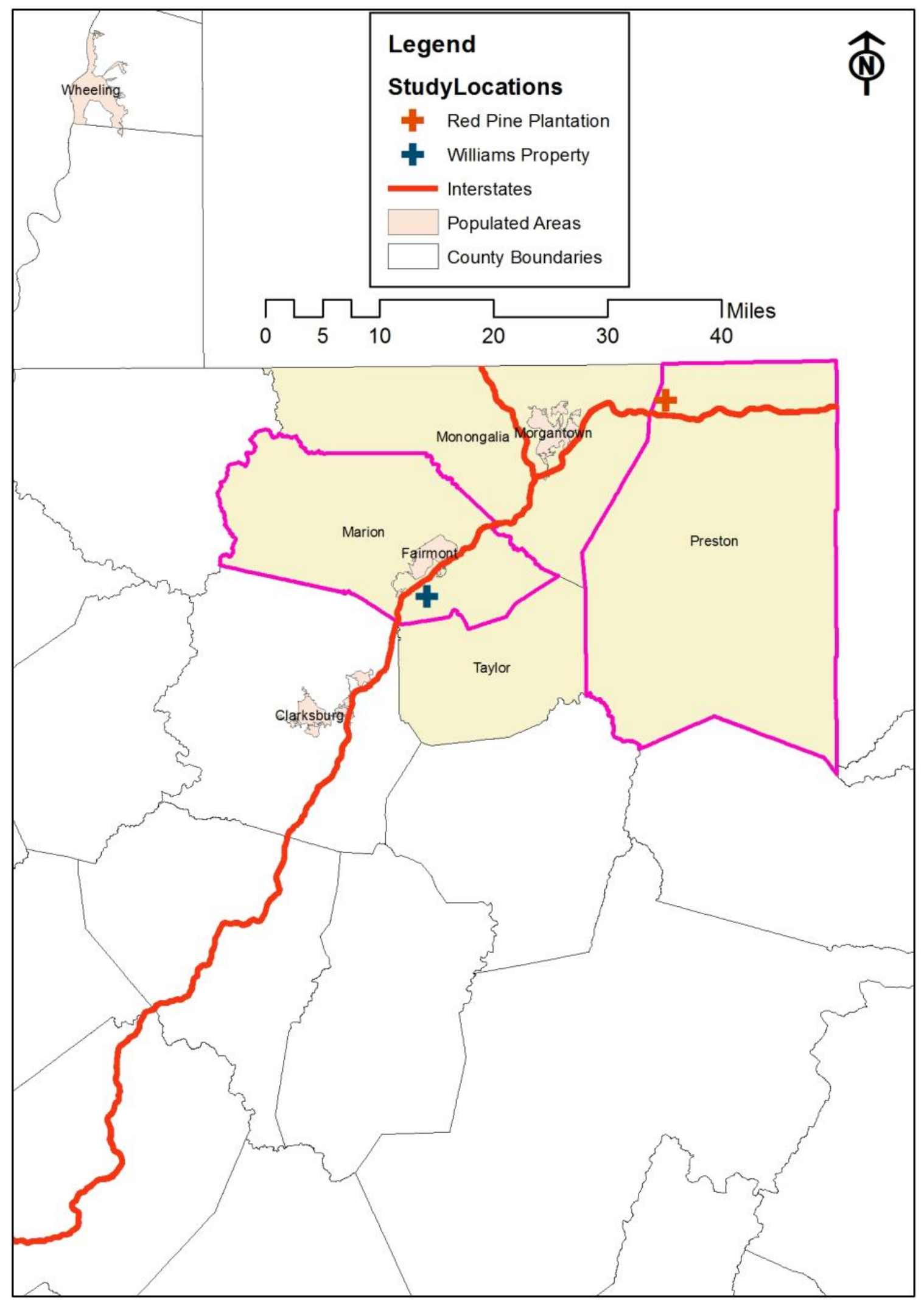

Figure 2.01 - General location of study sites in North-Central West Virginia. 
The WVU research forest site was located in a red pine plantation that was established on a portion of an old farm field that was part of the Sandford Ryan farm (Fig 2.02). The site was cleared in the 1850's after previously been owned by the Greenville Furnace and Mining Company of Brandonville, WV. Aerial photographs from 1938 indicate that the field was being used for pasture (Witt, 1981). Between 1938 and 1957, the area overgrew with scattered areas of brush, mostly black locust and shrubby St. John's-wort (Hypericum spathulatum). The state of West Virginia acquired the land in 1936. In 1941, red pine seedlings, of unknown origin, were planted with a $1.5-2-m$ spacing. Site pruning occurred in 1955, removing braches from the lower two meters of boles. In 1970, pruning was extended to five-meters. In 1971, the first commercial crown thinning removed $36 \%$ of basal area. The soil in the area is of the Dekalb channery sandy loam series. The site-index (red oak base 50) of the plantation is 74 (Witt, 1981). The site had an $8 \%$ slope and a south-facing aspect. The average elevation of the stand was $662 \mathrm{~m}$.

Currently, at the WVU research forest site (Figures 2.02, 2.04, 2.06), red maple (Acer rubrum) makes up a majority of the number of trees in the small to medium DBH size classes, indicating a changing of the forest make up from previously dominating red pine (Pinus resinosa) and yellow-poplar (Liriodendron tulipifera). Black cherry (Prunus serotina) is persistent throughout all size classes. Other trees at this site include white ash (Fraxinus americana), cucumber tree (Magnolia accuminata), blackgum (Nyssa sylvatica), sassafras (Sassafras albidum), white oak (Quercus alba), and northern red oak (Q. rubra). Currently the red pine plantation has 415 trees per hectare (TPH) with $19.42 \mathrm{~m}^{2}$ basal area (BA) per hectare.

The Colfax site (on the private property of Mr. and Mrs. Brent Williams), is located adjacent to the Tygart River near Colfax in Marion County, West Virginia (Fig 2.03). This property has a northwest aspect with a gentle topography and is located in a fertile river valley. The woodlot contains trees that are mostly considered sawtimber size (at least $30 \mathrm{~cm} \mathrm{DBH}$ ) and predominately made up of yellow-poplar (L. tulipifera), white ash (F. americana), and black cherry ( $P$. serotina) but is also interspersed with red maple ( $A$. rubrum) and sugar maple ( $A$. saccharum). Smaller timber may be found throughout the woodlot, but most is considered low 
density with high basal area (Wildman, 2008). The site index for the stand is 80 . Elevation on the property ranged from $270 \mathrm{~m}$ along the Tygart River to $347 \mathrm{~m}$ along the western boundary.

In 2008 the Williams property underwent a forest stand improvement treatment in the form of grapevine removal through the help of the West Virginia Department of Forestry (WVDOF) and the Natural Resources Conservation Service (NRCS). The purpose of the program was to increase the quantity and quality of forest products on the land through the manipulation of understory species composition, stand structure and stocking by cutting or killing selected trees and understory vegetation. Grapevines were killed by severing in order to cease present damage and prevent future damage that may reduce quality to the high-valued hardwood stands on the property. Prior to treatment, approximately 250-375 TPH were affected by grapevines (NRCS, 2009). Locations of individual treatments are marked (Figure 2.03).

Current stand structure (Figures 2.05 and 2.07) for the Colfax site includes high basal area for large yellow-poplar trees interspersed with medium-sized black cherry and white ash. A large majority of the small, sapling sized trees are made up of sugar maple in the understory. The 12 hectare stand is currently stocked with $840 \mathrm{TPH}$ and $47.83 \mathrm{~m}^{2}$ BA per hectare (Figures 2.04 and 2.06).

For trees that were at least $5 \mathrm{~cm} \mathrm{DBH}$, Colfax exhibited many more trees on a per-hectare basis. There were $840 \mathrm{TPH}$ at the Colfax site compared to $415 \mathrm{TPH}$ at the West Virginia Research Forest site (Figures 2.04 and 2.05). Forest composition at the Colfax site was completely different. By far, the majority of medium to large trees were yellow-poplar, while the small DBH size classes that dominated the understory were sugar maple. Almost $22 \%$ of the basal area at the Colfax site (Figure 2.07) was made up of trees greater than $75 \mathrm{~cm} \mathrm{DBH}$. 


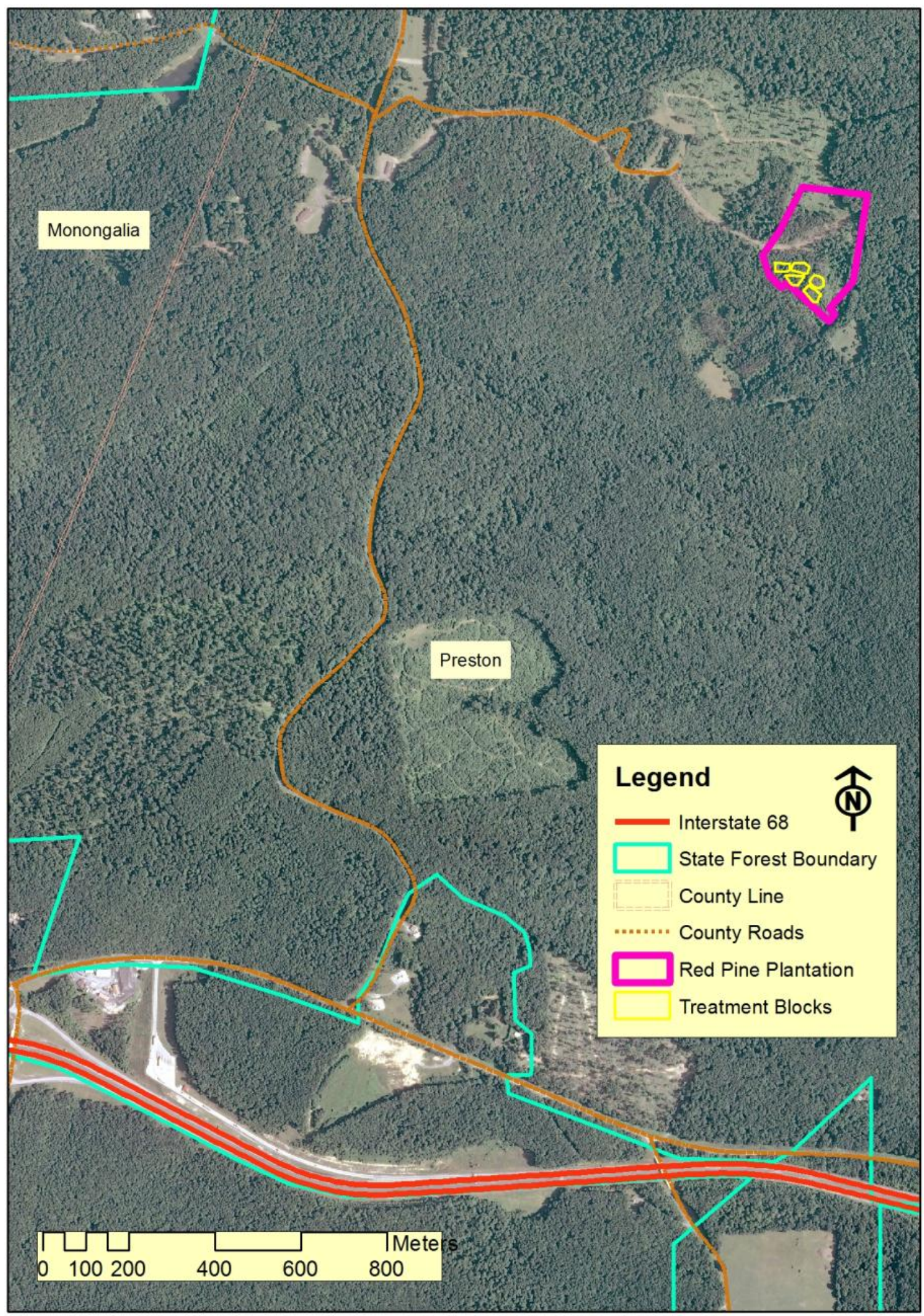

Figure 2.02 - Study site at the West Virginia University Research Forest, Preston County, WV. 


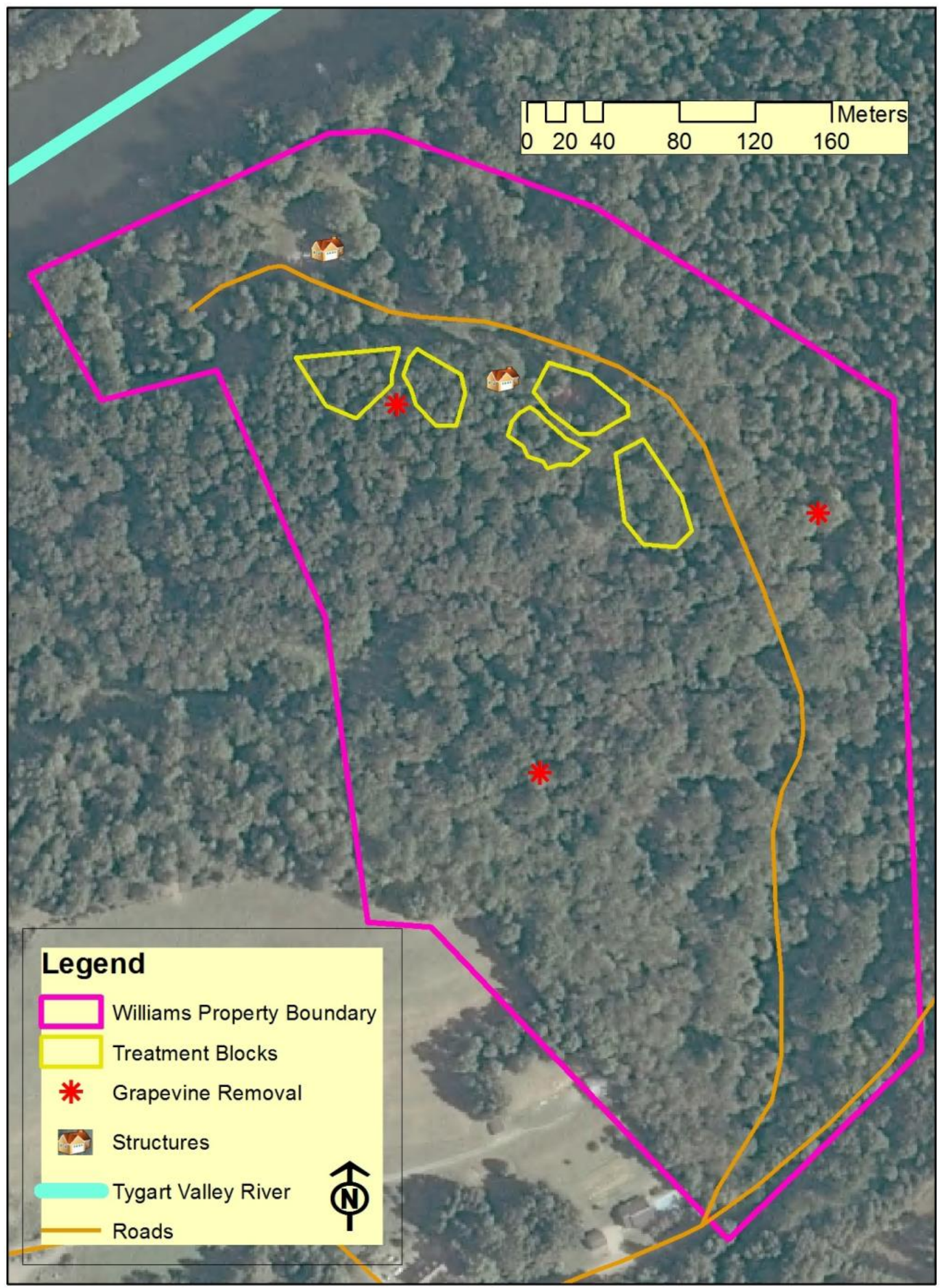

Figure 2.03 - Study site in Colfax, Marion County, WV. 


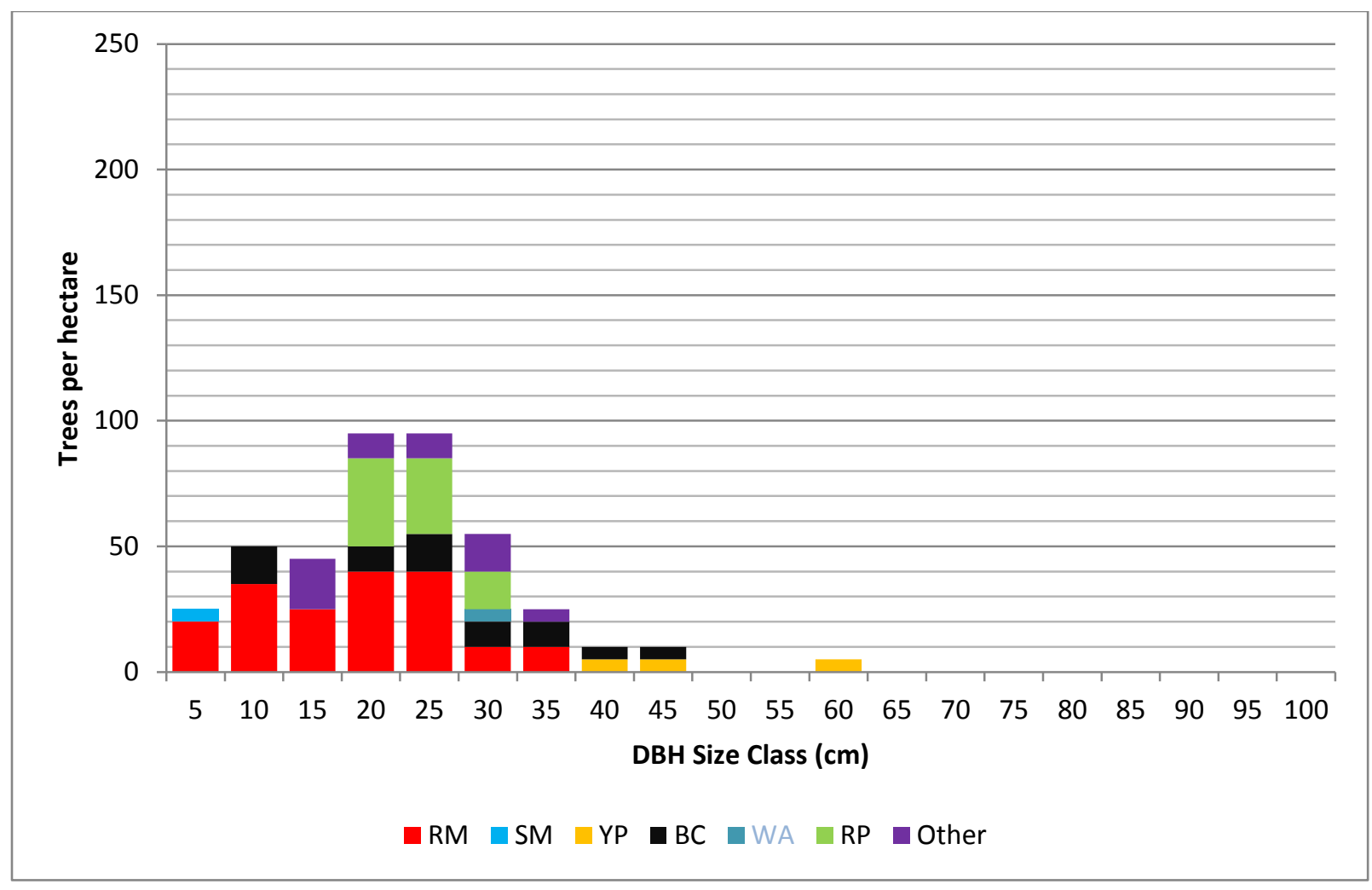

Figure 2.04 - WVU Research Forest trees per hectare by DBH $(\mathrm{cm})$ size class and species.

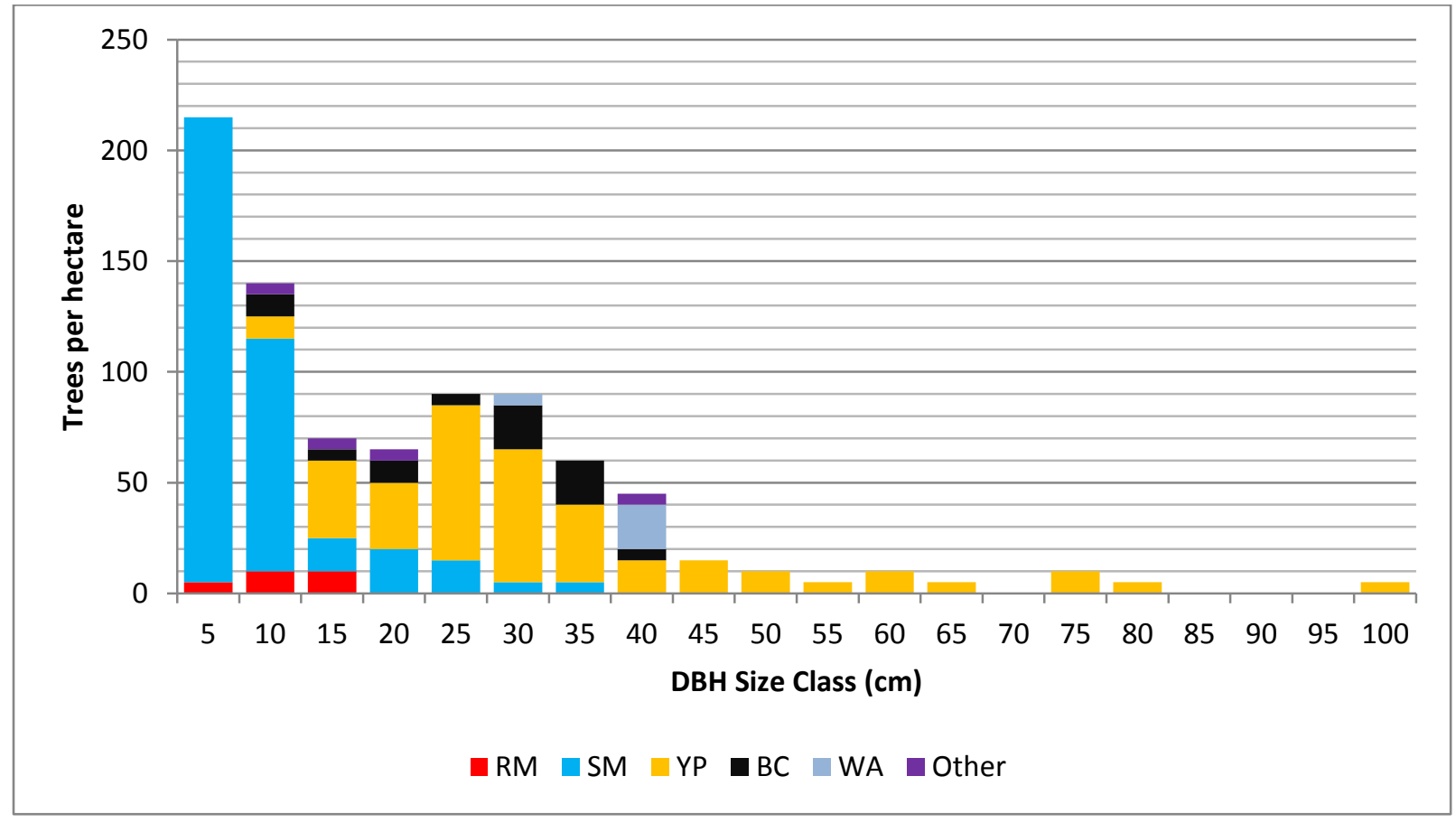

Figure 2.05 - Colfax trees per hectare by DBH $(\mathrm{cm})$ size class and species. 


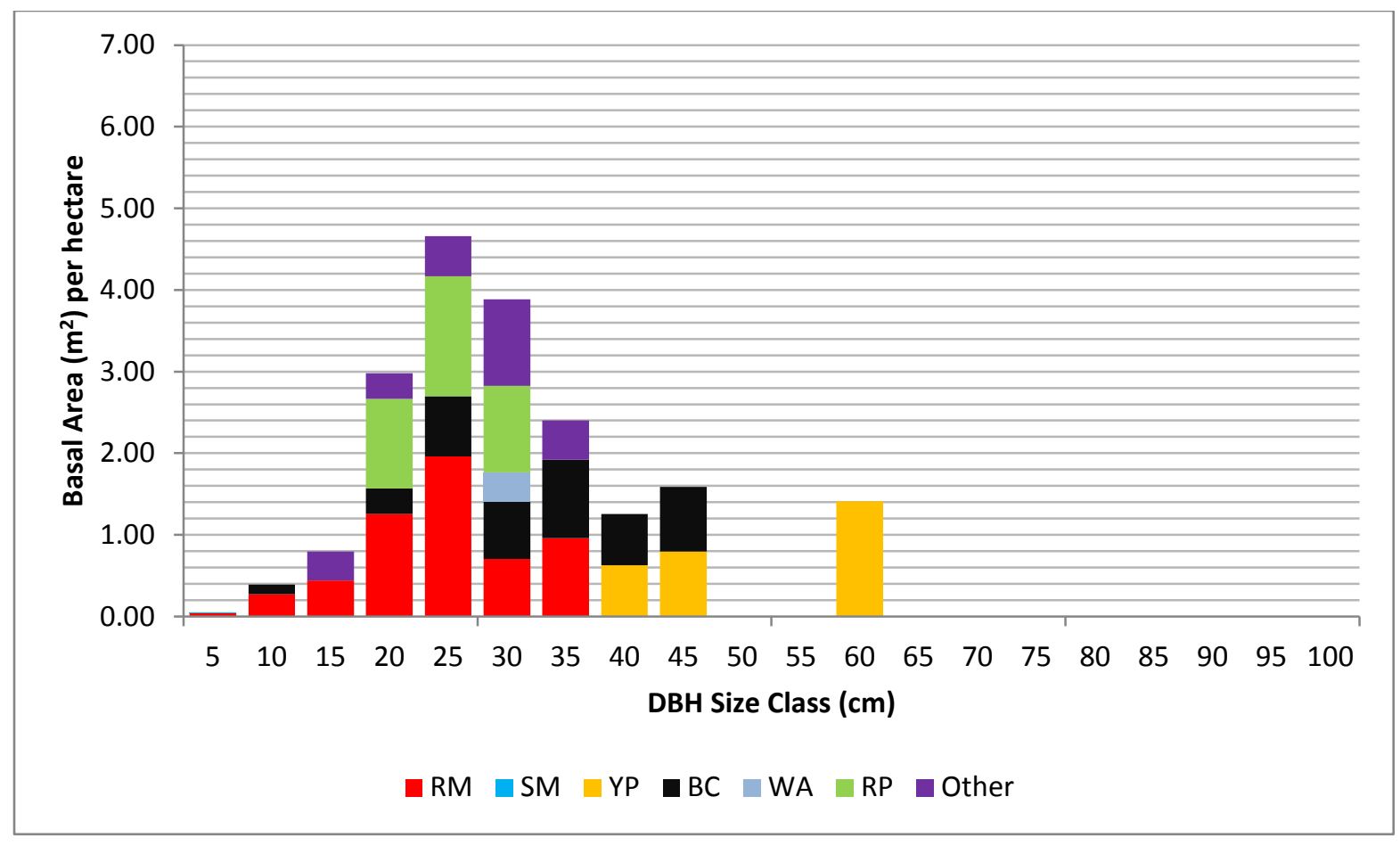

Figure 2.06 - WVU Research Forest total basal area $\left(\mathrm{m}^{2}\right)$ per hectare total by DBH size class and species.



Figure 2.07 - Colfax total basal area $\left(\mathrm{m}^{2}\right)$ per hectare by DBH size class and species. 


\section{ii. Understory Conditions}

A concave spherical densiometer was used for the measurement of general canopy cover over each of the five blocks at each site. Measurements (Lemmon, 1956) were taken at the center of each block, or as close to the center as possible without an obstructed view. Measurements were taken four times at the approximate center of each block, facing in each of four directions: north, south, east, and west. Measurements were averaged at each block and then averaged by block at each site. The average crown closure at the WVU Research Forest was $70 \%$, while the average crown closure at the Colfax Site was $77 \%$.

Crown closure is one way of estimating the amount of light that penetrates the canopy of a forest. Crown closure varies seasonally and can directly affect photosynthetically active radiation (PAR) (Baldocchi et al., 1986). During the growing season, leaves are present in the canopy of a forest inhibiting the penetration of PAR. An AccuPAR model LP-80 PAR/LAI Ceptometer light wand was used to estimate the amount of PAR that reached the forest floor at each of the understory plants. PAR readings in the form of $\mu \mathrm{Mol} / \mathrm{m}^{2} \mathrm{~s}$ were taken at the crown of each of the 80 plants at each site. Measurements were taken at midday in order to best represent light penetration through the canopy to each plant. The WVU Research Forest Site had an average PAR reading of $18.85 \mu \mathrm{Mol} / \mathrm{m}^{2} \mathrm{~s}$ and the Colfax Site had an average PAR reading of $20.03 \mu \mathrm{Mol} / \mathrm{m}^{2} \mathrm{~s}$.

\section{iii. Materials}

Foliar application of Accord Concentrate ${ }^{\circledR}$ was used as the source of glyphosate. For foliar application, a lateral zig-zag motion over the whole plant is recommended in order to ensure that at least 50 percent of the leaves are contacted by the spray solution (DowAgro, 2006).

Cide-Kick $\|{ }^{\circledR}$ was the surfactant used in this study. Cide-Kick $\|^{\circledR}$ is a low-viscosity oil and a nonionic penetrant and has an active ingredient of limonene (100\%) that is extracted from the bark of pine trees (Brewer, 2000 Label). It is a wetting agent, sticker, activator, and penetrant all in one that helps break down waxy cuticles on the surface of leaves. It also helps penetrate 
the bud and bark area of the plant to allow for better uptake of the herbicide (Brewer, 2000 Label).

The application device was a 1 gallon Solo ${ }^{\circledR}$ Model 456 Compression Sprayer fitted with a flatspray tip. The device was calibrated by testing the spray amount over different spray periods at a constant pressure. The device was calibrated to deliver $24 \mathrm{ml} / \mathrm{s}$ (Figure 2.08).

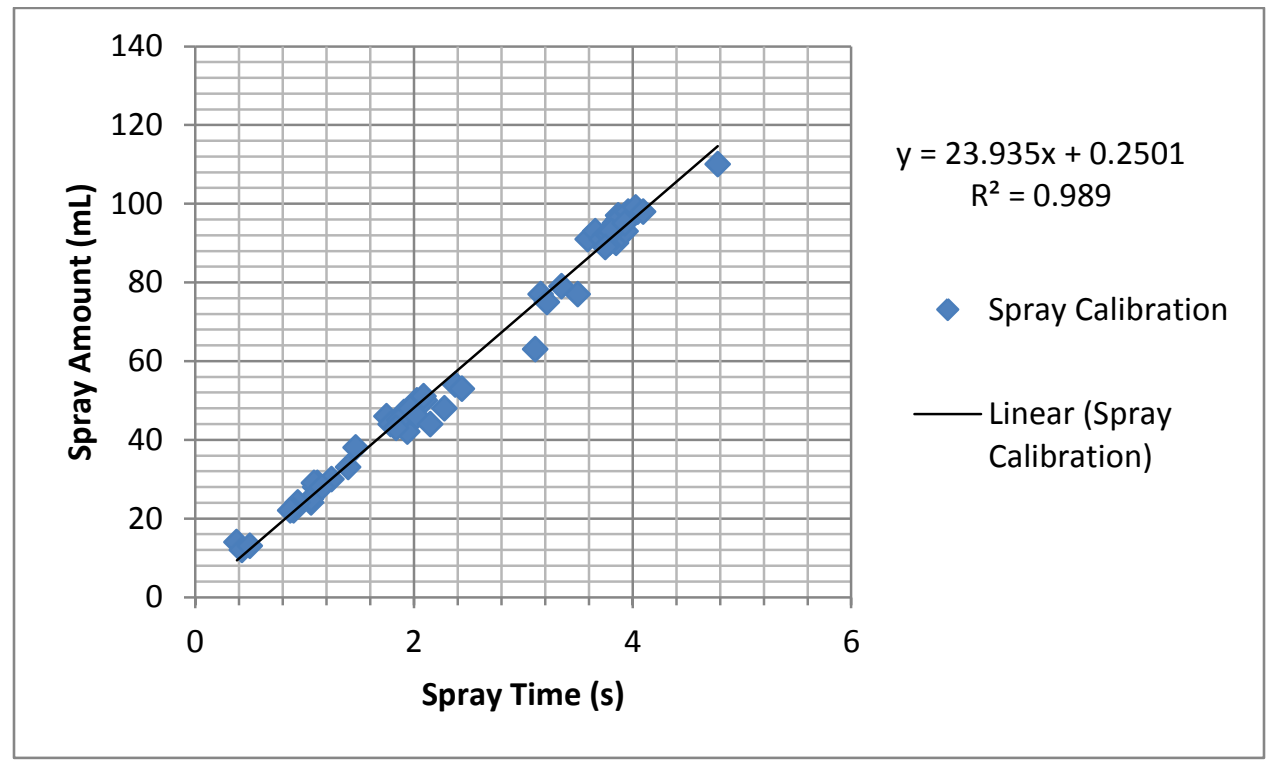

Figure 2.08 - Calibration Compression Sprayer fitted with a flat-spray tip. 


\section{iv. Average C. Orbiculatus dimensions and diameters for selected stems}

Measurements of $C$. orbiculatus crown volume were taken at each site. Approximate length, width and height $(\mathrm{cm})$ were taken and crown volumes $\left(\mathrm{m}^{3}\right)$ were calculated. The average aboveground volume for plants at the WVU research forest site was $0.255 \mathrm{~m}^{3}$ which was significantly $(p=0.04)$ larger than the average at the Colfax which was $0.157 \mathrm{~m}^{3}$. Stem diameters of selected plants measured with a caliper to the nearest one thousandth $\mathrm{cm}$. Stem diameters at the WVU research forest site were significantly ( $p=0.001)$ larger, at $0.190 \mathrm{~cm}$, compared to the Colfax site at $0.156 \mathrm{~cm}$ (Table 2.01).

Table 2.01 - Average stem diameter and aboveground volume of understory plants by site.

\begin{tabular}{rccccc}
\hline Site & Length $(\mathrm{cm})$ & Width $(\mathrm{cm})$ & Height $(\mathrm{cm})$ & Volume $\left(\mathrm{m}^{3}\right)$ & Stem Diameter $(\mathrm{cm})$ \\
\hline WVU & 76 & 47 & 53 & 0.255 & 0.190 \\
Colfax & 59 & 40 & 55 & 0.157 & 0.156 \\
\hline
\end{tabular}

\section{v. Experimental Design}

Four levels of herbicide $(0,2.5,5$, and 10 percent by volume) were crossed with four levels of surfactant $(0,0.5,1$, and 2 percent by volume) to create 16 treatments (Table 2.02). Treatments pre-mixed with distilled water and randomly assigned to five blocks of 16 plants at each site 
Table 2.02 - Treatments with breakdown of volume to volume constituents (\%V/V , \& Liters/hectare active ingredient).

\begin{tabular}{|c|c|c|c|c|}
\hline & \multicolumn{4}{|c|}{ Surfactant: Cide-Kick II ${ }^{\circledR}$} \\
\hline $\begin{array}{c}\text { Herbicide: } \\
\text { Accord } \\
\text { Concentrate }^{\circledR}\end{array}$ & $\begin{array}{c}0 \% \\
0 \mathrm{~L} / \mathrm{H} \\
(\mathrm{Al})\end{array}$ & $\begin{array}{c}0.5 \% \\
9.76 \mathrm{~L} / \mathrm{H} \\
(\mathrm{Al})\end{array}$ & $\begin{array}{c}1 \% \\
18.26 \mathrm{~L} / \mathrm{H} \\
\text { (Al) }\end{array}$ & $\begin{array}{c}2 \% \\
41.74 \mathrm{~L} / \mathrm{H} \\
\text { (Al) }\end{array}$ \\
\hline $\begin{array}{c}0 \% \\
0 \mathrm{~L} / \mathrm{H} \\
(\mathrm{Al})\end{array}$ & $\begin{array}{c}\text { 1A } \\
\text { OmL Herbicide } \\
\text { Oml Surfactant } \\
1000 \mathrm{ml} \mathrm{H} 20\end{array}$ & $\begin{array}{c}\text { 1B } \\
\text { OmL Herbicide } \\
5 \mathrm{ml} \text { Surfactant } \\
995 \mathrm{ml} \mathrm{H} 20\end{array}$ & $\begin{array}{c}1 \mathrm{C} \\
\text { OmL Herbicide } \\
\text { 10ml Surfactant } \\
990 \mathrm{ml} \mathrm{H} 20\end{array}$ & $\begin{array}{c}\text { 1D } \\
\text { OmL Herbicide } \\
\text { 20ml Surfactant } \\
980 \mathrm{ml} \mathrm{H20}\end{array}$ \\
\hline $\begin{array}{c}2.5 \% \\
22.92 \mathrm{~L} / \mathrm{H} \\
(\mathrm{Al})\end{array}$ & $\begin{array}{c}2 \mathrm{~A} \\
25 \mathrm{~mL} \text { Herbicide } \\
\text { Oml Surfactant } \\
1000 \mathrm{ml} \mathrm{H} 20\end{array}$ & $\begin{array}{c}\text { 2B } \\
\text { 25mL Herbicide } \\
5 \mathrm{ml} \text { Surfactant } \\
970 \mathrm{ml} \mathrm{H} 20\end{array}$ & $\begin{array}{c}2 \mathrm{C} \\
25 \mathrm{~mL} \text { Herbicide } \\
10 \mathrm{ml} \text { Surfactant } \\
965 \mathrm{ml} \mathrm{H} 20\end{array}$ & $\begin{array}{c}\text { 2D } \\
\text { 25mL Herbicide } \\
\text { 20ml Surfactant } \\
955 \mathrm{ml} \mathrm{H} 20\end{array}$ \\
\hline $\begin{array}{c}5 \% \\
54.92 \mathrm{~L} / \mathrm{H} \\
\text { (Al) }\end{array}$ & $\begin{array}{c}\mathrm{A} \\
\text { 50mL Herbicide } \\
\text { Oml Surfactant } \\
\text { 1000ml H20 }\end{array}$ & $\begin{array}{c}3 \mathrm{~B} \\
50 \mathrm{~mL} \text { Herbicide } \\
5 \mathrm{ml} \text { Surfactant } \\
945 \mathrm{ml} \mathrm{H} 20\end{array}$ & $\begin{array}{c}3 \mathrm{C} \\
50 \mathrm{~mL} \text { Herbicide } \\
10 \mathrm{ml} \text { Surfactant } \\
940 \mathrm{ml} \mathrm{H} 20\end{array}$ & $\begin{array}{c}\text { 3D } \\
50 \mathrm{~mL} \text { Herbicide } \\
\text { 20ml Surfactant } \\
930 \mathrm{ml} \mathrm{H} 20\end{array}$ \\
\hline $\begin{array}{c}10 \% \\
115.77 \mathrm{~L} / \mathrm{H} \\
\text { (Al) }\end{array}$ & $\begin{array}{c}4 \mathrm{~A} \\
\text { 100mL Herbicide } \\
\text { Oml Surfactant } \\
\text { 1000ml H20 }\end{array}$ & $\begin{array}{c}4 \mathrm{~B} \\
100 \mathrm{~mL} \text { Herbicide } \\
5 \mathrm{ml} \text { Surfactant } \\
895 \mathrm{ml} \mathrm{H} 20\end{array}$ & $\begin{array}{c}4 \mathrm{C} \\
\text { 100mL Herbicide } \\
10 \mathrm{ml} \text { Surfactant } \\
890 \mathrm{ml} \mathrm{H} 20\end{array}$ & $\begin{array}{c}\text { 4D } \\
\text { 100mL Herbicide } \\
\text { 20ml Surfactant } \\
880 \mathrm{ml} \mathrm{H} 20\end{array}$ \\
\hline
\end{tabular}

\section{vi. Application}

Treatments were applied over the course of two days, July 16 th and $17^{\text {th }}, 2011$. Application was carried out beginning in late morning, using two identical Solo ${ }^{\circledR}$ brand 1 gallon pressure sprayers each fitted with identical flat spray tips. Because there were 16 treatments and only two sprayers, each sprayer had to be used multiple times. Sprayer one was used to apply treatment $1 \mathrm{~A}$ to one plant in each of the 5 blocks at each site. Sprayer two was then used to apply treatment $1 \mathrm{~B}$ to one plant in each block. While sprayer two was in use, sprayer one was washed and rinsed in the field and prepared to use for treatment $1 \mathrm{C}$. Alternating sprayers were used for every other of the 16 treatments.

Individual stems were sprayed until all leaves were wet, but not to the point of runoff. The amount of time for the spraying of each plant was recorded in order to determine amount of treatment sprayed on each plant. Plants in each of the five blocks were treated in succession starting with the lowest herbicide levels and moving up as treatments progressed.

Environmental conditions at the time of application (Table 2.03) show that very similar weather conditions existed for both sites. There was a rainfall event that passed through, causing 
measureable precipitation at both sites on July $19^{\text {th }}, 2011$. However, this should not have had an effect on the uptake of the herbicide by the plant.

Table 2.03 - Environmental conditions at time of application.

\begin{tabular}{rcc}
\hline Site & WVU Research Forest & Colfax \\
\hline Date & July $16^{\text {th }}, 2011$ & July $17^{\text {th }}, 2011$ \\
Min Temp & $17^{\circ} \mathrm{C}$ & $17^{\circ} \mathrm{C}$ \\
Mean Temp & $24^{\circ} \mathrm{C}$ & $24^{\circ} \mathrm{C}$ \\
Max Temp & $30^{\circ} \mathrm{C}$ & $30^{\circ} \mathrm{C}$ \\
Precipitation & $0.0 \mathrm{~mm}$ & $0.0 \mathrm{~mm}$ \\
Previous Precipitation & July $11^{\text {th }}, 2011$ & July $13^{\text {th }}, 2011$ \\
& $5.6 \mathrm{~mm}$ & $2.5 \mathrm{~mm}$ \\
\hline
\end{tabular}

\section{vii. Analysis}

Evaluation of understory $C$. orbiculatus plants lasted for 14 weeks from the date of treatment application (July 16th and 17th) to the end of the growing season. If a plant was determined to express any of the symptoms at any one time, it was marked for that evaluation. Damage categories (outlined in table 2.04) were predetermined and chosen based on common plant symptoms that included chlorosis and necrosis (Boerboom and Broeske; Evans, 2012). Each plant was noted for the week after treatment (WAT) of first expression of each of the predetermined attributes. Additionally, survival after the application was determined in the following spring where plants were checked for the presence of live tissue and any resprouting.

Table 2.04 - List of explanatory variables and levels.

\begin{tabular}{rc}
\hline Explanatory Variable & Levels \\
\hline Glyphosate Level & $0,2.5,5,10 \%$ by volume \\
Surfactant Level & $0,0.5,1,2 \%$ by volume \\
Site & WV Research Forest Site, Colfax Site \\
Block & $1,2,3,4$, or $5 *$ \\
\hline
\end{tabular}

*Block numbers had no significance other than for spatial reference

Multivariate analysis of variance (MANOVA) is a statistical procedure for comparing the population means of several groups (Haase and Ellis, 1987). The model used for MANOVA included the predetermined indicator attributes as the response variables. The explanatory variables were glyphosate, surfactant, GLYxSurf (interaction), Site, and Block. The response variables were indicator attributes expressed by the plants and measured for first appearance (WAT). Attributes (Table 2.04) that were evaluated included: tip curling, tip chlorosis, tip 
necrosis, lateral leaf deformation, lateral leaf chlorosis, lateral leaf necrosis, total leaf chlorosis, and total leaf loss.

Multivariate (MANOVA) and Univariate Analysis of Variance (ANOVA) were used to compare the week of first appearance for each attribute within each treatment. The tests were performed using SAS 9.1 software (SAS Institute, 2003) using the General Linear Model (GLM) procedure. The significance level for the test was set at alpha $=0.05$.

The purpose of a t-test is to assess the probability that the means for two groups are sampled from the same sampling distribution of means (Dowdy et al., 2004). The purpose of analysis of variance (ANOVA) is to test that the means for two or more groups are taken from the same sampling distribution (Dowdy et al., 2004). The purpose of multivariate analysis of variance (MANOVA) is to test whether or not the vectors of means for two or more groups are sampled from the same sampling distribution, indicating a global effect (French et al., 2008).

MANOVA searches for and identifies whether or not different levels of the explanatory variables have a significant effect on a linear combination of each of the response variables (French et al. 2008). In the context of this study, MANOVA checks whether or not glyphosate, surfactant, site and block have a significant effect on the combined attributes' (response variables) week of first appearance after treatment (WAT).

In order to test for any significant effects MANOVA test statistics are generated with their own F-distribution. There are four test statistics generated through MANOVA, each one is a function of the eigenvalues, or characteristic or latent roots, of the matrix of raw data. Wilks' lambda is the pooled ratio of error variance to effect variance plus error variance (French et al., 2008); Pillai's trace is the pooled effect variances; Hotelling-Lawley's trace is the pooled ratio of effect variance to error variance; and Roy's greatest root is the largest eigenvalue (Carey, 1998).

Literature on MANOVA varies widely on the interpretation of MANOVA statistics. Wilks' lambda is generally the most common and most widely used statistic (Everitt and Dunn, 1991; Polit, 1996), also it returns an exact F-value (French et al. 2008). Pillai's trace is considered the most robust and powerful test statistic but it returns the most conservative F-statistic (French et al., 2008). Both Hotelling-Lawley's trace and Roy's greatest root are susceptible to outlying eigenvalues (Olsen, 1976). Because Roy's greatest root is dependent on the largest eigenvalue, it often returns a significant result when other MANOVA tests do not, when this occurs, Roy's greatest root can be ignored (Carey, 1998). For MANOVA in this study, because it is the most common and widely used (Everitt and Dunn, 1991; Polit, 1996), Wilks' lambda test statistic was used to determine the global effect. For this study, Wilks' lambda was used due to it being the most common and widely used statistic. 
If a global effect of explanatory variables is found, it is important to explore univariate F-tests to interpret the respective effect on the individual response variables (French et al., 2008). Univariate analysis of variance (ANOVA) provides a test for significant differences between means (StatSoft, 2012). The model used in this study is a simple linear (GLM) model where the dependent variable is the week of first appearance of each individual attribute, and the explanatory variables are levels of glyphosate, surfactant, site, and block.

Table 2.05 - Attribute damage categories (response variables) with descriptions and examples.

\begin{tabular}{|c|c|c|}
\hline $\begin{array}{l}\text { Damage } \\
\text { Categories }\end{array}$ & Description & Example \\
\hline No Effect & $\begin{array}{l}\text { Plant displays no ill } \\
\text { effects. No discoloration } \\
\text { or deformities. All in all } \\
\text { plant looks healthy and } \\
\text { appears not to be } \\
\text { affected by herbicides. }\end{array}$ & \\
\hline Tip Curling & $\begin{array}{l}\text { Leaf tips of plant } \\
\text { express slight unnatural } \\
\text { curl when compared to } \\
\text { the leaves of a healthy } \\
\text { plant. }\end{array}$ & \\
\hline
\end{tabular}


Table 2.05 - Attribute damage categories (Continued).

\begin{tabular}{|l|l|l|l|l|}
$\begin{array}{l}\text { Damage } \\
\text { Categories }\end{array}$ & $\begin{array}{l}\text { Description } \\
\text { Tip Chlorosis }\end{array}$ & $\begin{array}{l}\text { Leaf tips of plant } \\
\text { express a discoloration } \\
\text { (usually yellowing) but } \\
\text { majority of leaf remains } \\
\text { unaffected }\end{array}$ & Example \\
\hline Tip Necrosis & $\begin{array}{l}\text { Tips of leaves express } \\
\text { browning and dieback } \\
\text { but majority of leaf } \\
\text { appears unaffected. }\end{array}$ &
\end{tabular}


Table 2.05 - Attribute damage categories (Continued).

\begin{tabular}{|l|l|l|}
\hline $\begin{array}{l}\text { Damage } \\
\text { Categories }\end{array}$ & Example \\
\hline Deformation & $\begin{array}{l}\text { Lateral Leaves along } \\
\text { vine stem are physically } \\
\text { altered to where the no } \\
\text { longer have the same } \\
\text { shape as healthy leaves }\end{array}$ \\
\hline Chlorosis & $\begin{array}{l}\text { Lateral leaves along vine } \\
\text { stem express } \\
\text { discoloration (usually } \\
\text { yellowing). }\end{array}$ & \\
\hline
\end{tabular}




\begin{tabular}{|l|l|l|l|}
\hline Lateral Leaf & $\begin{array}{l}\text { Lateral leaves along vine } \\
\text { stem express browning } \\
\text { and dieback but a } \\
\text { portion of the leaf } \\
\text { remains }\end{array}$
\end{tabular}

Table 2.05 - Attribute damage categories (Continued).

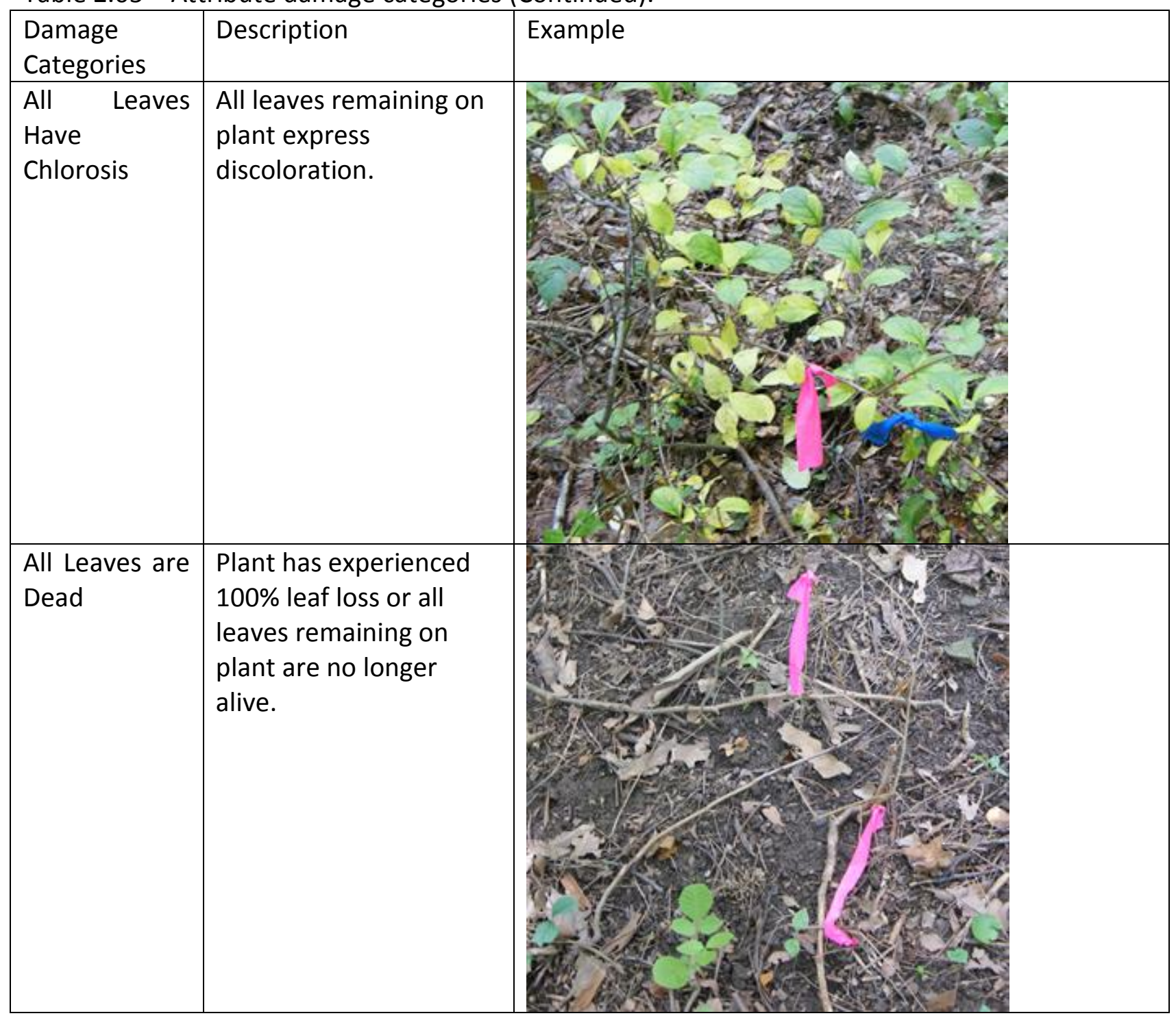




\begin{tabular}{|l|l|l|}
\hline $\begin{array}{l}\text { Re-sprouting } \\
\text { Along Stem }\end{array}$ & $\begin{array}{l}\text { Plant has express ill } \\
\text { effects of herbicide } \\
\text { damage but is now } \\
\text { showing signs of re- } \\
\text { sprouting leaves along } \\
\text { stem. }\end{array}$ & $\begin{array}{l}* * \text { Study plants did not express this attribute within } \\
\text { study timeframe** }\end{array}$ \\
\hline $\begin{array}{l}\text { Re-sprouting } \\
\text { at Base }\end{array}$ & $\begin{array}{l}\text { Plant has not } \\
\text { completely died but } \\
\text { new sprouts are present } \\
\text { along basal stem. }\end{array}$ & $\begin{array}{l}* * \text { Study plants did not express this attribute within } \\
\text { study timeframe** }\end{array}$ \\
\hline $\begin{array}{l}\text { Root } \\
\text { Sprouting }\end{array}$ & $\begin{array}{l}\text { Plant has appeared to } \\
\text { die, but sprouts have } \\
\text { appear around root } \\
\text { system }\end{array}$ & $\begin{array}{l}* * \text { Study plants did not express this attribute within } \\
\text { study timeframe** }\end{array}$ \\
\hline
\end{tabular}

\section{Results \\ i. Survival}

Plants were evaluated in late March 2012 to check for possible re-sprouting and/or regrowth. Plants were also re-evaluated for survival by checking for live plant material at the base of each stem. Evaluation of survival indicated that plants that received $0 \%$ glyphosate treatment $(\mathrm{n}=$ 40; Control, plus $0.5 \%, 1 \%, \& 2 \%$ Surfactant only) expressed $75 \%$ survival. Survival of plants receiving recommended rates ( $2.5 \%$ glyphosate, $0.5 \%$ surfactant) of herbicide was $0 \%$ indicating that this lowest level of herbicide rate is the most cost effective. Of the plants receiving other glyphosate treatments $(n=120)$ only one plant $(>1 \%)$ survived (Figure 2.09$)$.

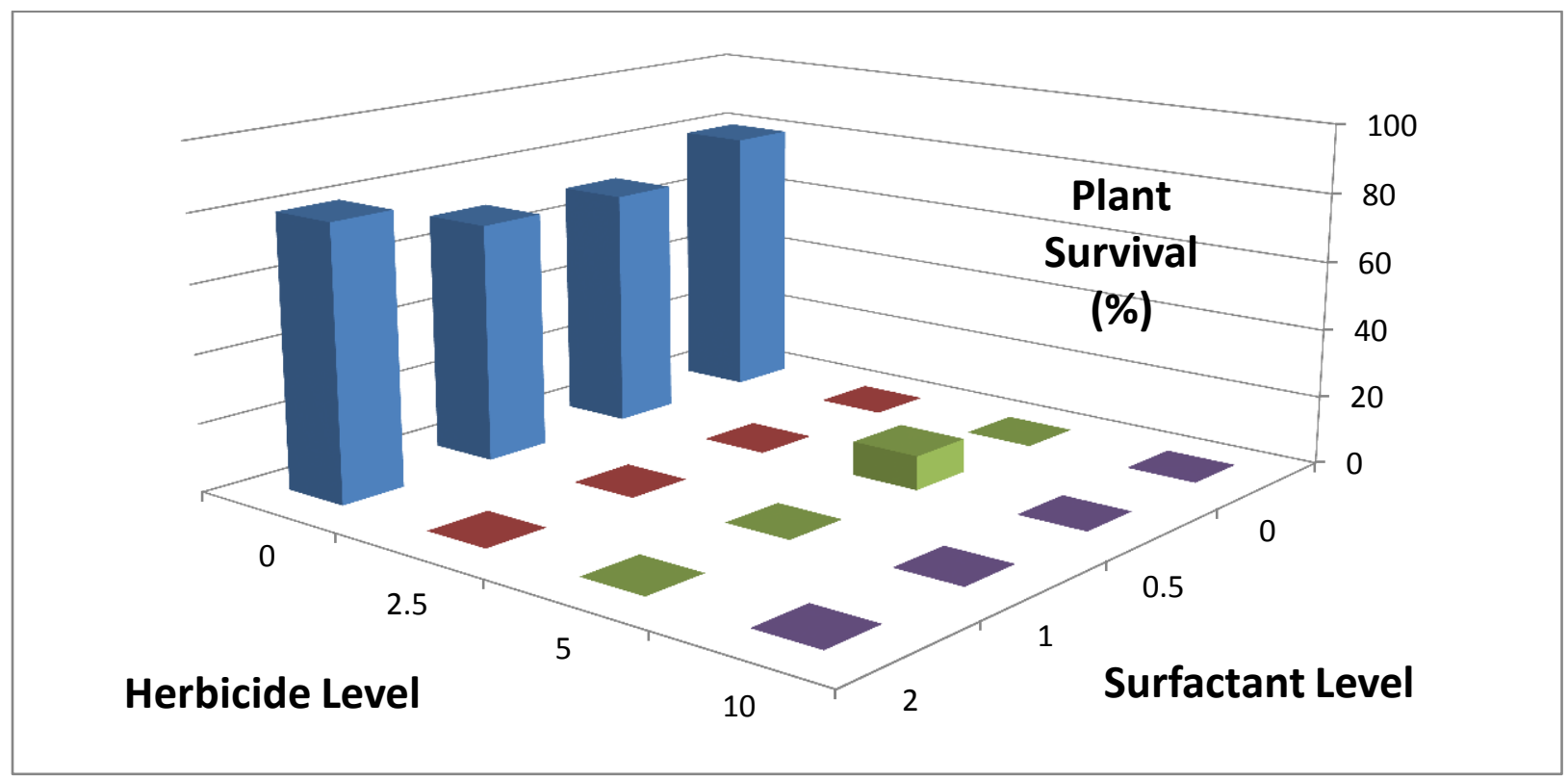


Figure 2.09 - Percent survival of plants by treatment, March, 2012.

\section{ii. Analysis of Week After Treatment of Attribute Appearance}

Tables 2.05 and 2.06 lists p-values resulting from the test for differences between the means of the first week of appearance of each damage attribute. Bold values indicate a statistically significant ( $\alpha=0.05$ ) result showing that there is a given effect from the explanatory variable on the response variable.

Table 2.06 - P-Values for MANOVA model.

\begin{tabular}{llllll}
\multicolumn{7}{l}{ Effect } \\
Statistic & Glyphosate & Surfactant & GLY*SURF & Site & Block \\
\hline Wilks' Lambda & $<\mathbf{0 . 0 0 0 1}$ & 0.82 & 0.73 & $\mathbf{0 . 0 0 0 4}$ & 0.18 \\
Pillai's Trace & $<\mathbf{0 . 0 0 0 1}$ & 0.82 & 0.72 & $\mathbf{0 . 0 0 0 4}$ & 0.18 \\
Hotelling-Lawley Trace & $<\mathbf{0 . 0 0 0 1}$ & 0.83 & 0.73 & $\mathbf{0 . 0 0 0 4}$ & 0.17 \\
Roy's Greatest Root & $<\mathbf{0 . 0 0 0 1}$ & 0.31 & $\mathbf{0 . 0 0 5}$ & $\mathbf{0 . 0 0 0 4}$ & $\mathbf{0 . 0 0 5}$ \\
\hline
\end{tabular}

Table 2.07 P-values for ANOVA model for each attribute $(\mathrm{N}=160)$.

\begin{tabular}{llllll}
\hline Response Variables & \multicolumn{5}{c}{ Explanatory Variables } \\
\hline Attribute & Glyphosate & Surfactant & GLY*Surf & Site & Block \\
\hline Tip Curling & $<\mathbf{0 . 0 0 0 1}$ & 0.94 & 0.46 & 0.62 & 0.83 \\
Tip Chlorosis & $<\mathbf{0 . 0 0 0 1}$ & 0.54 & 0.56 & 0.93 & 0.42 \\
Tip Necrosis & $<\mathbf{0 . 0 0 0 1}$ & 0.64 & 0.83 & 0.94 & 0.52 \\
Lateral Leaf Deformation & $<\mathbf{0 . 0 0 0 1}$ & 0.31 & 0.84 & 0.14 & 0.10 \\
Lateral Leaf Chlorosis & $<\mathbf{0 . 0 0 0 1}$ & 0.81 & 0.93 & $\mathbf{0 . 0 0 2}$ & 0.30 \\
Lateral Leaf Necrosis & $<\mathbf{0 . 0 0 0 1}$ & 0.06 & 0.06 & 0.29 & $\mathbf{0 . 0 3}$ \\
Total Leaf Chlorosis & $<\mathbf{0 . 0 0 0 1}$ & 0.58 & 0.87 & $\mathbf{0 . 0 0 7}$ & 0.71 \\
Total Leaf Loss & $<\mathbf{0 . 0 0 0 1}$ & 0.64 & 0.47 & $\mathbf{0 . 0 0 1}$ & 0.26 \\
\hline
\end{tabular}

a. GLY x Surf Effect (interaction)

MANOVA returned a Wilks' lambda test statistic indicating no interaction (GLY*Surf) effect on the week of first appearance for any of the attributes. The ANOVA model also showed that the interaction term was not statically significant for any of the damage attributes.

b. Glyphosate Effect 
The MANOVA test of differences between groups using the Wilks' Lambda criteria was statistically significant among Glyphosate $(F(24,383.44)=22.33 ; p<0.0001)$ treatments.

ANOVA of the data shows that each indicator attribute exhibited a glyphosate effect. P-values for the Glyphosate effect were all < 0.0001 (Table 2.06). The week of first appearance of each attribute was affected by the rate of glyphosate.

\section{c. Surfactant Effect}

Both MANOVA and ANOVA returned statistically non-significant results $(\alpha=0.05)$ for a surfactant effect for any attributes. Surfactant does not have an effect on the week of first appearance for any of the attributes.

\section{d. Site Effect}

MANOVA showed a statistically significant site effect. Wilks' Lambda criteria was statistically significant among Site $(F(8,132)=3.86 ; p=0.0004)$ treatments. There is a significant global site effect.

ANOVA showed that site had a significant effect on three response variables: Lateral leaf chlorosis, total leaf necrosis, and total leaf loss. This may be due to the difference in site makeup. A look at various site measurements between the two site locations (Table 2.08) reveals some differences between their physical make-ups. The WVU research forest site was located at an elevation that was more than double the Colfax site. Other major differences between sites include average selected plant above ground volume, where plants at the WV Research Forest site were significantly $(p=0.04)$ larger than the Colfax site. WVU research forest site plants also had significantly larger $(p=0.001)$ stem diameters. Trees per hectare and basal area per hectare also varied quite a bit between the two sites (Table 2.06).

Table 2.08. Site Comparisons (Bold attributes are major differences between sites).

\begin{tabular}{|c|c|c|}
\hline & WVU Research Forest Site & Colfax Site \\
\hline Average Elevation & $662 \mathrm{~m}$ & $309 \mathrm{~m}$ \\
\hline Site Index & 74 & 80 \\
\hline Crown Closure & $71 \%$ & $78 \%$ \\
\hline Light Penetration & $19 \mu \mathrm{Mol} / \mathrm{m}^{2} \mathrm{~s}$ & $20 \mu \mathrm{Mol} / \mathrm{m}^{2} \mathrm{~s}$ \\
\hline Dominant Tree Species & yellow-poplar & yellow-poplar \\
\hline Plant Size & $0.255 \mathrm{~m}^{3}$ & $0.153 \mathrm{~m}^{3}$ \\
\hline Selected Stem Diameter & $0.190 \mathrm{~cm}$ & $0.156 \mathrm{~cm}$ \\
\hline Basal Area per hectare & $19.4 \mathrm{~m}^{2}$ & $47.8 \mathrm{~m}^{2}$ \\
\hline Trees per hectare & 415 & 840 \\
\hline
\end{tabular}

e. Block Effect 
MANOVA returned statistically non-significant results for Wilks' lambda; Roy's Greatest Root can be ignored indicating that there was not a significant global block effect. ANOVA returned statistically significant results $(\alpha=0.05)$ for a block effect for lateral leaf necrosis. For this study, block was used to keep track of the general spatial placement of selected plants at each site.

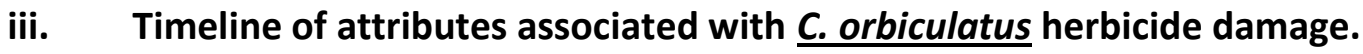

Indicators of plant response to herbicide treatment are important in determining the efficacy of treatments in the control of a plant. Visual symptoms expressed by aboveground portions of a plant can be taken as indicators of efficacy. The attributes described in the study were expressed at different times and can be used to develop a model for what to expect when $C$. orbiculatus succumbs to herbicide treatments. Table 2.07 outlines the average week after treatment (WAT) of first appearance for each attribute for control plants, plants receiving the recommended rate of $2.5 \%$ glyphosate and $0.5 \%$ surfactant, plants receiving a glyphosate treatment, and plants receiving only surfactant as a treatment.

Table 2.09 - Average week of first appearance by attribute

\begin{tabular}{lllll}
\hline Attribute & Control & $\begin{array}{l}\text { Surfactant } \\
\text { Only }\end{array}$ & $\begin{array}{l}\text { With } \\
\text { Glyphosate }\end{array}$ & $\begin{array}{l}\text { Recommended } \\
\text { Rate }\end{array}$ \\
\hline Tip Curling & 10.8 & 9.4 & 1.6 & 1.1 \\
Tip Chlorosis & 11.4 & 9.1 & 1.4 & 1.1 \\
Tip Necrosis & 10.4 & 10.7 & 2.1 & 2.1 \\
Lateral Leaf Deformation & 11.2 & 11.6 & 2.8 & 4.1 \\
Lateral Leaf Chlorosis & 13.2 & 13.2 & 3.6 & 3.4 \\
Lateral Leaf Necrosis & 13.4 & 13.9 & 5.6 & 4 \\
Total Leaf Chlorosis & 14 & 14.0 & 9 & 4.5 \\
Total Leaf Loss & 14 & 13.0 & 6.1 & 6.8 \\
\hline
\end{tabular}

Control plants represent the best estimate of how an understory $C$. orbiculatus plant naturally responds to seasonal change. Figure 2.09 is a timeline that helps to illustrate when these attributes are expressed and how they are expressed in relationship to each other as the growing season ends. In late fall, control plants first express tip chlorosis followed closely by tip curling. Then after approximately a week tip necrosis is expressed. After about another week, 
lateral leaves begin to express chlorosis and deformation followed about a week later by necrosis. Finally, total leaf necrosis and total leaf loss indicate that the growing season, for $C$. orbiculatus is over.

Plants treated only with surfactant expressed "leaf damage" attributes at very similar times as the controls. A visual comparison of Figures 2.09 and 2.10 (p. 51) shows a noticeable difference between surfactant and control plants, especially the tip curling and tip chlorosis attributes.

Plants treated with herbicide expressed damage attributes at a much earlier time period. On average, a plant treated with Glyphosate (any level), expressed damage attributes 9.8 weeks sooner than the controls. Glyphosate treated plants began showing symptoms as soon as 1.4 WAT. Comparing figures 2.09 and 2.11 present a good indication of the difference.

Recommended Glyphosate treatment for the control of $C$. orbiculatus was found to be $2.5 \%$ by volume herbicide with a $0.5 \%$ non-ionic surfactant (URI, 2007; Bergmann \& Swearingen 1999; SEPPC, 2003). Figure 2.12 shows that plants that received the recommended treatment expressed damage attributes, on average, 8.9 weeks earlier than the control plants. It is interesting to note that some of the more popular and sought after indicators of efficacy such as leaf chlorosis and leaf loss where not expressed in the plants until as late as 4, 5, and even 7 WAT. The delayed response to recommended rates may be due to the mode of action of glyphosate herbicides where the plants continue to grow until stored amino acids are exhausted. Knowing that an immediate response may not occur and that attributes may take a little longer to show up may help determining the efficacy of recommended treatments in later studies. 
Timelines of average attribute appearance for various treatments.

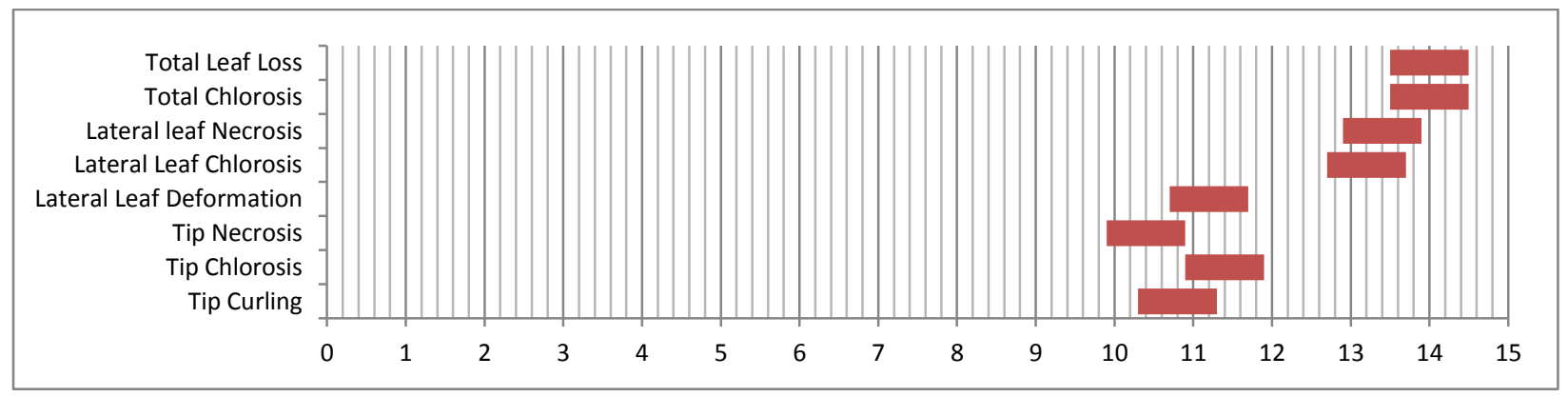

Figure 2.10 - Average appearance of attributes (WAT) for control plants.

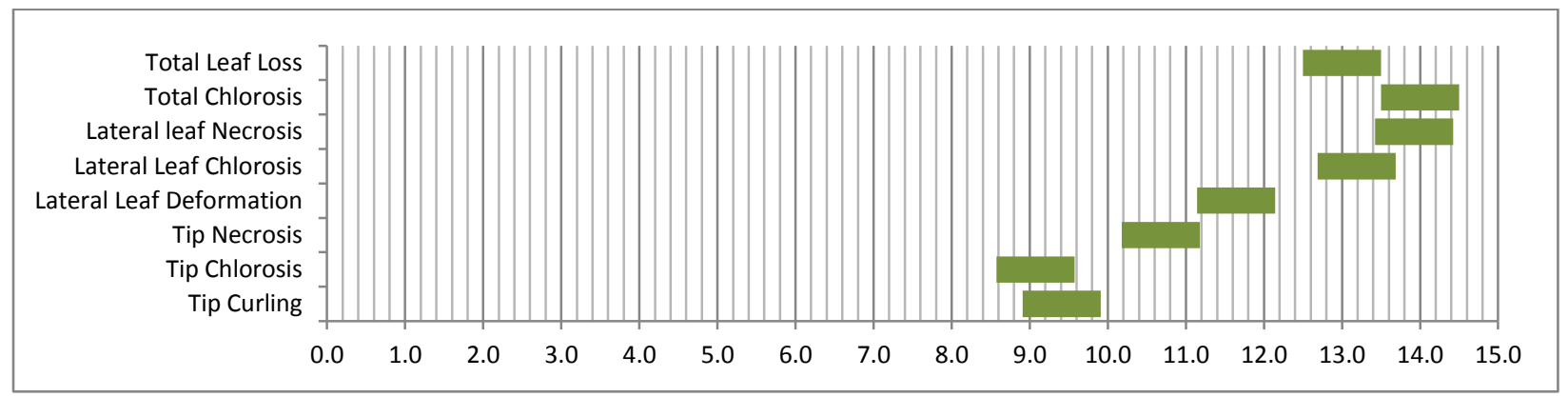

Figure 2.11 - Average appearance of attributes (WAT) for plants treated with surfactant only. 


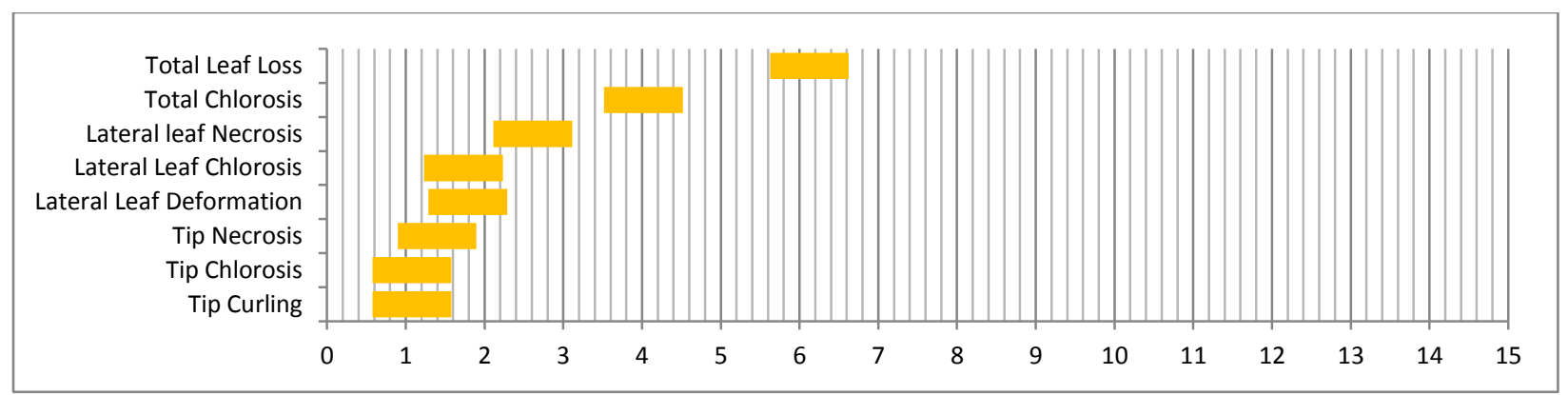

Figure 2.12 - Average appearance of attributes (WAT) for Glyphosate-treated plants.

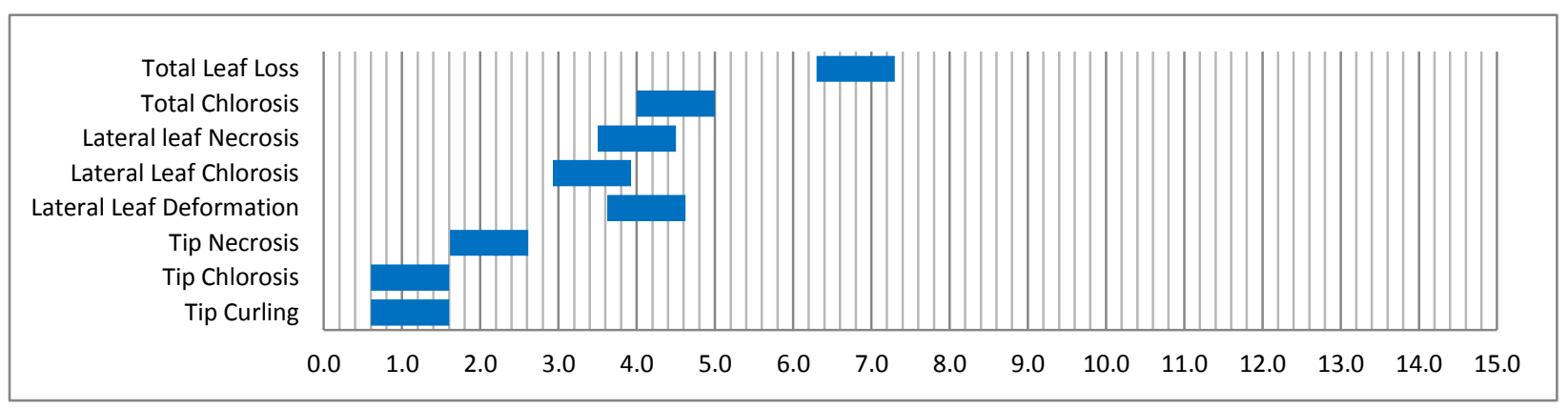

Figure 2.13 - Appearance of attributes (WAT) for plants treated with recommended rates.

\section{Discussion}

This study was carried out in order to help develop more concrete evidence for recommended controls for a problematic invasive plant species. All treatment levels of glyphosate in this study had an effect on when the understory $C$. orbiculatus plant expressed indicator attributes. Since all levels were effective, the lowest combined treatment levels of glyphosate and surfactant would be a recommended rate, $2-2.5 \%$ glyphosate and $0.5 \%$ surfactant. Higher rates would not be cost effective.

Literature on C. orbiculatus tended to lump control methods in with most other vine and woody weed species. Ahrens (1987) conducted a study to find effective herbicides for the control of $C$. orbiculatus. Fourteen foliar spray treatments of various herbicide formulations that included various dosages of glyphosate, triclopyr, imazapyr, sulfometuron, and combinations of glyphosate with triclopyr, and imazapyr with sulfometuron, combined with a fixed $5 \%$ surfactant were conducted on 60, $3.3 \times 3.3$ meter fixed area plots. The highest rate of glyphosate (2\%) was found to be effective exhibiting $80 \%$ control a year after treatment, but regrowth from seed was evident. Lower glyphosate treatments resulted only in leaf deformation greatly suppressed growth. Triclopyr and imazapyr expressed $96-100 \%$ control of bittersweet in treated plots. 
Dreyer (1988) carried out a study on the efficacy of triclopyr on root-kill of $C$. orbiculatus and other weeds. 6 large scale $\left(25 \mathrm{~m}^{2}\right)$ plots were treated using a $2 \%$ volume to volume glyphosate and $5 \%$ amitrole foliar sprays resulted in $70 \%$ stem control with glyphosate and no control with amitrole. Percent of coverage by $C$. orbiculatus was noticeably reduced, where populations existed originally, down to low levels (0-2\%). Polatin (2006) found that "by far the most effective treatment for controlling bittersweet and allowing for grass establishment" was the combination of mowing and triclopyr treatments.

Hutchinson (1992) found that mechanical removal plus cut-stump method using a glyphosate or triclopyr based herbicide controlled $C$. orbiculatus, but failed to provide details on the magnitude of effectiveness. Miller (2002) indicated successful control with a cut stump method with glyphosate or triclopyr based herbicides, however also failed to expand on efficacy. Lynch (2009) looked at the efficacy of four recommended treatments in controlling C. orbiculatus while also comparing treatments to deer browse. Treatments included mechanical cutting, basal bark application with a $20 \%$ triclopyr ester (Garlon $4^{\circledR}$ ), and cut-stump with a $50 \%$ glyphosate mixture $\left(\right.$ Accord $\left.^{\circledR}\right)$. Lynch found that the only treatment that exhibited $100 \%$ control was basal bark treatments of Garlon $4^{\circledR}$.

Ahrens (1987), Dreyer (1988), Hutchinson (1992), Miller (2002), and Lynch (2009) all found that glyphosate, combined with additional methods, expressed effective control for $C$. orbiculatus. This study helps solidify findings that glyphosate, along with other systemic herbicides, when used by themselves at recommended levels can provide sufficient control for $C$. orbiculatus.

A local landowner had undesired results with recommended rates for the control of $C$. orbiculatus, claiming that much higher rates were needed for adequate control. The results of this study indicate that the recommended rate of $2-4 \%$ glyphosate and $0.5 \%$ surfactant would be sufficient to control understory plants. One possible reason for the land owner's undesired results may have been a timing factor. It is possible that the landowner did not wait long enough for plants to express damage attributes. A three week waiting time would be best suited to allow for damage attributes to be expressed by the plants.

A closer look at how the plants respond to herbicide damage or seasonal change indicates that there may be a difference in the timeframe in which indicator attributes are expressed. This has implications in how someone, wishing to control infestations of $C$. orbiculatus, approaches the problem. Knowing the timeframe at which to expect certain indicator attributes helps an applicator to gauge the efficacy of the treatment.

Not knowing how a plant reacts to herbicide treatments can lead to overuse of herbicides. The over-application of any chemical herbicide, which can have detrimental effects to the immediate surrounding environment, may also lead to the development of plant resistance to 
the herbicide, where the plant develops a mechanism to withstand a normally effective herbicide dose as a result of selection pressure (Harper, 1956), limiting the effectiveness of chemical control. Even though plants treated with glyphosate in the past have developed almost no chemical resistance (Bradshaw et al., 1997), there is still the possibility that resistance may develop. Knowing how a plant responds to treatment allows the applicator to understand what to look for to indicate efficacy.

Timing of application of systemic herbicides is important for efficacy. Plants express seasonal translocation of nutrients (Day, Jr. and Monk, 1977). In spring, nutrients stored from the previous growing season translocate from the below-ground root system upwards to the above-ground biomass (Chapin III et al., 1980). At the end of the growing season, essential nutrients are then moved downward from the above-ground biomass to be stored in the root system for the dormant season. Systemic herbicides are most effective when applied towards the end of the growing season when the chemicals can be transported easier to the root system to affect the entire plant (Feng et al., 2000).

The recommended rates of glyphosate and surfactant for the control (Hoyle, 2004; Miller et al. 2010; Swearingen et al. 2010) of C. orbiculatus may lead people to believe that it is immediately effective and will take care of the infestation within a couple weeks. This is not the case. This study showed that for recommended rates, the first signs of majority or whole plant effects did not occur until around 4 weeks after treatment.

Results from this study found that lowest tested treatment levels of Glyphosate exhibited adequate control of $C$. orbiculatus. Plants that received treatment levels of $2.5 \%$ (by volume) Glyphosate or higher expressed greater than $99 \%$ plant kill. This would indicate that the lowest rate of herbicide treatment in this study Is the most cost effective treatment. The main variation was when the plants expressed indicator attributes in a time-wise relation to when treatments were applied. Higher rates expressed attributes sooner. Recommended rates for adequate control of $C$. orbiculatus are $2.5 \%$ by volume glyphosate with $0.5 \%$ surfactant (URI, 2007; Bergmann \& Swearingen, 1999; SEEPPC, 2003).

\section{E. Conclusions}

There are a few points that can be extracted from this study. All levels of foliar glyphosate treatments tested were shown to be effective in controlling $C$. orbiculatus understory plants. No more than the recommended dosage of glyphosate is needed to show effective control for the plant. Lower rates of herbicide may indeed show control, but since they were not tested in this study, conclusions about their efficacy cannot be determined. Surfactant treatments alone did not control $C$. orbiculatus. There is variation present in the timing of average damage attribute expression, which may be part of a perception problem that may lead landowners 
wishing to control $C$. orbiculatus to think they are not seeing results and, in response, over apply herbicide. Results show a pattern of leaf damage due to glyphosate level. The study also documented the plants response to herbicide treatment over time as well as a seasonal pattern of leaf senescence in C. orbiculatus. 


\section{F. Literature Cited}

Ahrens, J. F. (1987). Herbicides for control of oriental bittersweet. Proceedings, Northeast Weed Science Society. 41. p167-170.

Baldocchi, D., B. Hutchison, D. Matt, R McMillen. (1986). Seasonal variation in the statistics of photosynthetically active radiation penetration in an oak-hickory forest. Agricultural and Forest Meteorology. 36. p343-61.

Bergmann, C., and J. M. Swearingen. (1999). Fact sheet: Oriental bittersweet--Celastrus orbiculatus Thunb. Weeds gone wild: Alien plant invaders of natural areas. The Plant Conservation Alliance's Alien Plant Working Group (Producer). February 20, 2011 <http://www.nps.gov/plants/alien/fact/ceor1.htm>

Bradshaw, L.D., S. R. Padgette, S. L. Kimball, and B. H. Wells. (1997). Perspectives on glyphosate resistance. Weed Technology. 11. p 189-98.

Brewer International. (2000). Cide Kick II Material Safety Data Sheet.

Brewer International. (2000). Cide Kick II Label.

Carey, G. (1998). Multivariate Analysis of Variance (MANOVA): I. Theory. Colorado University. Web. http://ibgwww.colorado.edu/ carey/p7291dir/handouts/manova1.pdf>.

Carey, G. (1998). Multivariate Analysis of Variance (MANOVA) II: Practical Guide to ANOVA and MANOVA for SAS. Colorado University. Web.

<http://ibgwww.colorado.edu/ carey/p7291dir/handouts/manova2.pdf>.

Chapin III, F. S., D. A. Johnson, J. D. McKendrick. (1980). Seasonal movement of nutrients in plants of differing growth form in an Alaskan tundra ecosystem: implications for herbivory. Journal of Ecology. 68. p189-209.

Day, Jr. , F. P., C. D. Monk. (1977). Seasonal nutrient dynamics in the vegetation on a southern Appalachian watershed. Amer. J. Bot. 64:9. p1126-39.

DowAgro. (2006). EPA Reg No. 62719-324 Specimen Label , D02-145-004 (EPA accepted 7/13/06; NY accepted 07/15/08; CA accepted 06/23/08).

Dowdy, S., S. Wearden, D. Chilko. (2004). Chapter 8: Students t distribution. Statistics for Research Third Edition. Wiley-Interscience. United States. p 190-210.

Dowdy, S., S. Wearden, D. Chilko. (2004). Chapter 10: Techniques for one-way analysis of variance. Statistics for Research Third Edition. Wiley-Interscience. United States. p 265-315. 
Dreyer, G. D.; L. M. Baird, and C. Fickler. (1987). Celastrus Scandens and Celastrus Orbiculatus: comparisons of reproductive potential between a native and an introduced woody vine. Bulletin of the Torrey Botanical Club. 114:3 p260-64.

Dreyer, G. D. (1988). Efficacy of triclopyr in rootkilling oriental bittersweet (Celastrus orbiculatus Thunb.) and certain other woody weeds. Proceedings, Northeastern Weed Sci. Soc. 42. p120121.

Evans, E. (2012). Herbicide injury symptoms. Horticultural Science. NC State University. College of Ag and life Sciences, Cooperative Extension. Web. March 15, 2012.

<http://www.ces.ncsu.edu/depts/hort/consumer/quickref/weedsherbicides/injury_symptoms.html>

Everitt B.S. \& Dunn G. (1991). Applied Multivariate Data Analysis. Edward Arnold. London. pp. 219-220.

Feng, P. C. C., J. J. Sandbrink, R. D. Sammons. (2000). Retention, uptake, and translocation of ${ }^{14} \mathrm{C}$-Glyphosate from track-spray applications and correlation to rainfastness in velvetleaf(Abutilon theophrasti). Weed Technology. 14. p127-32.

French, A., M. Macedo, J. Poulsen, T. Waterson, and A. Yu. (2008). Multivariate Analysis of Variance (MANOVA). San Francisco State University, 04 June 2008. Web. 20 Mar. 2012. <http://userwww.sfsu.edu/ efc/classes/biol710/manova/manovanewest.htm>.

Haase, R. F., and M. V. Ellis. (1987). Multivariate analysis of variance. Journal of Counseling Psychology. 34:4. p404-13.

Harper, J. L. (1956). The evolution of weeds in relation to the resistance to herbicides. Proc. 3rd Br. Weed Control Conf. 1.179-88.

Hoyle, Zoe. (2004). Oriental Bittersweet: A Patient Invader. News Releases from the Southern Research Station.

Hutchison, M. (1992) Vegetation management guideline: round-leaved bittersweet (Celastrus orbiculatus Thunb.). Natural Areas Journal. 12:3 p161.

IPSAWG - Invasive Plant Species Assesment Working Group. (2006). Invasive plants species fact sheet: oriental bittersweet Celastrus Orbiculatus. IPSAWG - Invasive Plant Species Assesment Working Group. Print.

Lemmon, P. E. (1956). A spherical densiometer for estimating forest overstory density. Forest Science. 2:1. p314-20. 
Lutz, H. J. (1943). Injuries to Trees Caused by Celastrus and Vitis. Bulletin of the Torrey Botanical Club. 70:4. p436-39. JSTOR. Web. 9 Feb. 2011. <http://www.jstor.org/stable/2481567>.

Lynch, A. L. (2009). Investigating distribution and treatments for effective mechanical and herbicide application for controlling oriental bittersweet (Celastrus orbiculatus Thunb.) vines in an Appalachian hardwood forest .Thesis. West Virginia University.

McNab, W. H., and M. Meeker. (1987). Oriental bittersweet: a growing threat to hardwood silviculture in the appalachians. Northern Journal of Applied Forestry. 4:4. p174-77. IngentaConnect. Web. 14 Feb. 2011.

Miller, J.H. (2002). Exotic pests and plants and their control. The Bugwood Network. <http://www.bugwood.org/weeds/forestexotics.html.>.

Miller, J.H., E.B Chambliss, N.J. Loewenstein. (2010). A field guide for the identification of invasive plants in southern forests. General Technical Report SRS-119. Asheville, NC. United States Department of Agriculture, Forest Service. p126.

NPIC - National Pesticide Information Center. (2010). Glyphosate General Fact Sheet. Web. <http://npic.orst.edu/factsheets/glyphogen.pdf>.

NPIC - National Pesticide Information Center. (2002). Triclopyr General Fact Sheet. NPIC. Web. <http://npic.orst.edu/factsheets/triclogen.pdf>.

NRCS - Natural Resources Conservation Service. US Department of Agriculture. (2009). NRCSCPA-1202. Forest Stand Improvement. EQIP 2008 743D4709071.

Olsen, C. L. (1976). On choosing a test statistic in multivariate analysis of variance. Psychological Bulletin. 83:4. P 579-586.

Polatin, C. C. 2006. Best management practices for controlling catbrier (Smilax rotundifolia), Oriental bittersweet (Celastrus orbiculatus), and scotch broom (Cytisus scoparius) on a coastal island in Massachusetts. Keene, NH: Thesis. Antioch University New England. 52 p.

Polit D.F. (1996) Data Analysis and Statistics for Nursing Research. Appleton and Lange, Stamford, Connecticut. pp. 320-321.

Pooler, M. R., R. L. Dix, and J. Feely. (2002). Interspecific hybridizations between the native bittersweet, Celastrus scandens, and the introduced invasive species, C. orbiculatus. Southeastern Naturalist. 1:1. p. 69-76. BioOne. Web.

SAS Institute Inc. (2003). SAS/ETS user's guide. Version 8.2. Second edition. Cary, NC: SAS Institute Inc. p 956. 
SE-EPPC. (2003) .Oriental Bittersweet, Celastrus Orbiculatus - Southeast exotic pest plant council invasive plant manual. Web. 07 Mar. 2012. <http://www.seeppc.org/manual/bittersweet.html>.

StatSoft. "ANOVA/MANOVA." ANOVA MANOVA. StatSoft Electronic Statistic Textbook. Web. 20 Mar. 2012. <http://www.statsoft.com/textbook/anova-manova/>.

Swearingen, J., B. Slattery, K. Reshetiloff, and S. Zwicker. 2010. Plant Invaders of Mid-Atlantic Natural Areas, 4th ed. National Park Service and U.S. Fish and Wildlife Service. Washington, DC. $168 p p$

URI CELS Outreach Center. (2007). Oriental Bittersweet (Celastrus Orbiculatus) Control Fact Sheet. URI CELS Outreach Center.

Wildman, J. (2008). Property of Mr. Brent Williams - West Virginia Forest Stewardship Program Land Management Program. West Virginia Department of Forestry Forest Stewardship Program.

Witt, R. K. (1981). A history and evaluation of the plantations at the West Virginia University Forest. Thesis. West Virginia University, Morgantown, WV. Print. 